\title{
A Spurious Solution to a Genuine Problem: An In- Depth Look at The Import Drugs Act of 1848
}

\section{Citation}

A Spurious Solution to a Genuine Problem: An In-Depth Look at The Import Drugs Act of 1848 (2002 Third Year Paper)

\section{Permanent link}

http://nrs.harvard.edu/urn-3:HUL.InstRepos:8846790

\section{Terms of Use}

This article was downloaded from Harvard University's DASH repository, and is made available under the terms and conditions applicable to Other Posted Material, as set forth at http:// nrs.harvard.edu/urn-3:HUL.InstRepos:dash.current.terms-of-use\#LAA

\section{Share Your Story}

The Harvard community has made this article openly available.

Please share how this access benefits you. Submit a story.

Accessibility 


\title{
A Spurious Solution to a Genuine Problem:
}

\author{
An In-Depth Look at \\ The Import Drugs Act of 1848
}

Angela Walch

Harvard Law School, Class of 2002

$3^{r d}$ Year Paper in satisfaction of the Written Work Requirement

Peter Barton Hutt, Adviser 


\section{Introduction}

On April 22, 2002, the Boston Globe reported that doctors had begun the process of identifying patients who may have been sold diluted drugs by Kansas City, Missouri pharmacist Robert Courtney ${ }^{1}$ In February, 2002, Courtney pleaded guilty to 20 counts of "tampering and adulterating or misbranding" two popular chemotherapy drugs; prosecutors believe he actually may have watered down 72 types of medicines prescribed for 4,200 patients in the past ten years. With every diluted dose, Courtney made "hundreds of dollars," enough in the long run to enable him to pay $\$ 600,000$ dollars in taxes, and to donate $\$ 1,000,000$ to his church. Today, Courtney sits in a Missouri jail, as he will for the next 17 to 30 years.

Robert Courtney is certainly not the first person to try to make money by adulterating drugs. Indeed, drug adulteration has been a problem since time immemorial, and nations all over the world have struggled to control it ${ }^{2}$ Here in the United States, the federal government made its first attempt to solve the problem of adulterated drugs with the passage of the Import Drugs Act (or the "Act") in June, 1848 ${ }^{3}$ The Act provided that the United States Customs Service would examine all imported drugs for purity, quality, and strength before allowing them into the United States. If the drugs did not meet the prescribed standard, they would be condemned or re-exported.

The Import Drugs Act has been relatively ignored by the academic community, and is most often relegated to a passing reference in a footnote. Yet the Act represents an important step in our nation's creation of a safe

\footnotetext{
${ }^{1}$ Josh Freed, Doctors Start Tally of Patients Given Watered-Down Drugs: Pharmacist Jailed for Role in Scheme, Boston Globe, April 22, 2002, at A3.

${ }^{2}$ In this paper, I use the term adulteration to mean "any procedure that produces an alteration in strength or purity or both, from the [declared] standard of the drug, whether through intent or neglect." See Ernst W. Stieb, Drug Control in Britain, 1850-1914, in Safeguarding the Public: Historical Aspects of Medicinal Drug Control, 15, (John B. Blake ed., 1970).

${ }^{3}$ Import Drugs Act, 9 Stat. 237 (1848).
} 
supply of drugs, and thus deserves some attention. In this paper, I give the Act that attention, and seek to place it in an historical context. In Chapter 1, I describe how Congressional action was prompted by medical conditions during the Mexican War and the belief that American soldiers were being given adulterated drugs. Chapter 2 describes the involvement of the professional health organizations in the fight against adulterated drugs, and suggests reasons why drug adulteration posed such a problem to doctors and pharmacists. In Chapter 3, I look at the legislative history of the Act, through an analysis of the House Report and the Congressional debates on the matter. Finally, in Chapter 4, I look at the mechanics of how the Act was implemented by the Customs Service, and describe its short term effects on the problem of adulterated drugs. 


\section{Chapter 1:}

\section{Drug Adulteration and the Mexican War}

The Import Drugs Act of 1848 was no doubt prompted in part by the medical conditions American soldiers faced during the Mexican War. The Mexican War ran from 1846 until 1848, and concluded with the ratification of the Treaty of Guadalupe Hidalgo a few months before the signing of the Import Drugs Act $4^{4}$ The end of the war dominated the Congressional agenda during the entire time the Import Drugs Act was under consideration. In its report (the "Committee Report") to Congress on the Import Drugs Act, the Select Committee on the Importation of Drugs (the "Committee") had noted its surprise "at the herculean portions of active medicines prescribed" by the army doctors ${ }^{5}$ At first, the Committee "w[as] disposed to trace many of these prescriptions to peculiarity of climate and endemic disease. $[6$ Their final conclusion, however, and a catalyst for the legislation, was that "the adulteration of the medicines used accounts for and fully justifies these seemingly extravagant prescriptions, and also explains the lamentable mortality attendant upon our troops." 7 During the Congressional debates on the Act, several Congressmen made reference to the poor

\footnotetext{
${ }^{4}$ The Treaty of Guadalupe Hidalgo was signed on January 31, 1848; ratified by the United States Senate on March 10, 1848; and ratified by the Mexican government on March 30, 1848. See James M. McCaffrey, Army of Manifest Destiny: The American Soldier in the Mexican War, 1846-1848 (1992) [hereinafter Army of Manifest Destiny].
}

${ }^{5}$ H.R. Rep. No. 30-664, at 20 (1848). The standard dosage of pure quinine was "a few grains." See id. at 7. The "herculean portions" described by Congress likely refer to dosages such as the twenty grains of quinine one doctor reported giving a soldier. See Dr. Thomas Neely Love, A Southern Lacrimosa: the Mexican War Journal of Dr. Thomas Neely Love, Surgeon 263 (H. Grady Howell, Jr. ed. 1995) [hereinafter Lacrimosa].

${ }^{6}$ H.R. Rep. No. 30-664, at 20.

${ }^{7}$ The full text of the Committee Report's discussion on adulterated drugs in the Mexican War is as follows:

"The reports of every day are filled with death. The gallant troops now in Mexico have dwindled frightfully before the diseases of that climate. That army possesses in its own tried valor an effectual element of protection from the present or any future enemy. It does not ask our protection from the foe; for this it looks to God and its won right arm; but "the arrow that flyeth at noonday, and the pestilence that walketh in darkness," are beyond their vigilance and prowess. Your committee, by frequent conversations with the surgeons in attendance upon our troops there, have been surprised at the herculean portions 
quality of drugs the American soldiers had received on the Mexican warfront. Congressman Hunt stated in the House debate on June 2, 1848, that "the importation of deleterious drugs had been very injurious to our army during the war with Mexico, and hence some action on this subject was loudly demanded." 8 Making this mistake right with the families of the dead soldiers was certainly a motivating force in passing the Act. In this chapter, I examine the claim that adulterated drugs were to blame for the high number of army deaths in the Mexican War. I also look at how Congress was able to use the Import Drugs Act as a salve for the pain and anger that American families may have felt over the Mexican War deaths. Ultimately, Congress may have been too willing to place the blame for soldiers' deaths on foreign adulterated drugs. The lack of funding for good doctors and adequate sanitary conditions, as well as the soldiers' own refusal to follow the sanitary regulations the army did have, likely contributed to the high number of deaths from disease - probably moreso than any adulterated drugs. Moreover, medical science was in such a primitive state that even fully potent drugs would have been ineffective against the soldiers' illnesses. In this chapter, I argue that blaming the deaths of American men on foreign adulterated drugs provided a handy explanation for Congress as the nation emerged from a controversial war. When a nation goes to war, its citizens expect to lose lives on the battlefield, but do not expect lives to be wasted in army camp epidemics. Blaming American soldiers' deaths on foreign drugs offered a way to unify a nation that was already split over the war, and was beginning to splinter over issues such as slavery and women's rights 9

of active medicines prescribed in many forms of illness. They were at first disposed to trace many of these prescriptions to peculiarity of climate and endemic disease. But the adulteration of the medicines used accounts for and fully justifies these seemingly extravagant prescriptions, and also explains the lamentable mortality attendant upon our troops. We are not aware of the existence of a law requiring inspection of drugs and medicine purchase for the army or navy. We believe no inspection is had in this department; and whilst a rigid examination of material for clothing and subsistence is demanded, the sick and wounded are left to him who furnishes agents necessary for their comfort and recovery, as the lowest bidder. We deem this a dangerous proceeding, and one imperiously demanding legislation." Id. at 20 ..

${ }^{8}$ Cong. Globe, $30^{\text {th }}$ Cong. $1^{\text {st }}$ Sess., 810 (1848).

${ }^{9}$ For a discussion of the social history of the United States during the Mexican War, see generally, Expansionism and Conflict. 
Though the United States won the war with Mexico, the two-year fight exacted a heavy toll on the American forces. Around 12,500 men were lost in the two years of the war; Congress would receive frequent news of more American deaths, as would the families and communities of the dead soldiers ${ }^{10}$ As the Committee Report noted, "the reports of every day are filled with death." ${ }^{11}$ Most often, though, the news was not that the soldiers had died in combat, but instead that the men had died of disease while at the front. The committee acknowledged in its report that "the number of our troops in Mexico who have perished in battle bears no proportion to those who have fallen victims to the climate and the exposure consequent on army life." 12 Indeed, during the two years of the war, almost 10,790 American soldiers died from disease, while less than 1,548 died in combat ${ }^{13}$ This sorry statistic made the Mexican War "the deadliest war the United States ever fought.:"14

\section{Congress Underfunds the War-Effort}

One of the primary reasons that so many soldiers died of disease was that Congress was a poor provider for the welfare of American soldiers. There simply was not enough funding to provide for healthy living conditions on the warfront. For example, Congress failed to appropriate funds to ensure that soldiers had Soldiering, Suffering, and Dying] (citing statistics from S. Exec. Doc. No. 34-96, at 605-606.). See also James McCaffrey, Santa Anna's Greatest Weapon: The Effect of Disease on the American Soldier During the Mexican War, Military History of the West, Fall 1994, at 111 [hereinafter Santa Anna's Greatest Weapon].

${ }^{14}$ Soldiering, Suffering and Dying at 285. The article compares the mortality rate of disease of the Mexican War to the Civil War, the Spanish-American War, World War I. The mortality rate of disease for each of the wars was as follows: Mexican War-110 per 1,000 per annum; Civil War-65 per 1,000 per annum; Spanish-American War-27.79 per 1,000 per annum; World War I-16 per 1,000 per annum. See id.
} 
proper clothing to protect against the elements ${ }^{15}$ The government provided very few of its soldiers with "wollen [sic] clothes and hardly one in ten with flannel." ${ }^{16}$ During the winter, soldiers slept in "paper-thin government issue tents" designed for hot summers ${ }^{17}$ One army doctor lamented that, "[o]ur sick men suffered very much from the want of [b]lankets \& mattresses to keep them warm." ${ }^{18}$ Soldiers also ran short of food, and what they had either lacked nutrition or was downright dangerous. At one camp on the Rio Grande, the soldiers existed on a diet of beans, pickled pork, flour, and "bug-infested biscuits." ${ }^{19}$ Government funding was so short that one doctor described lending "the government" twenty dollars to pay the rail fare for some sick soldiers ${ }^{20}$ In the end, he had such a hard time getting reimbursed that he regretted lending the money in the first place ${ }^{21}$ Bick troops refused to go from their camps to military hospitals because "they would not be attended to, and nothing given them to eat." 22 One sick soldier remarked "that it was only twenty five cents between that and going to Hell, and that he would prefer going to Hell." ${ }^{23}$ According to one doctor, "not until the seal of death had fixed the destiny of many a brave soldier, did our Government officers pretend to offer the least assistance. 24 Congress also skimped on funding for medical supplies. Army doctors experienced frequent shortages of medicines when cargo aboard ships sank en route, or was raided

\footnotetext{
${ }^{15}$ Id. at 297 .

${ }^{16}$ Lacrimosa at 255.

${ }^{17}$ Soldiering, Suffering, and Dying at 287.

${ }^{18}$ Lacrimosa at 81.

${ }^{19}$ Soldiering, Suffering, and Dying at 289.

${ }^{20}$ Lacrimosa at 35 .

${ }^{21} I d$.

${ }^{22} I d$.

${ }^{23} I d$.

${ }^{24}$ Id.at 257 .
} 
by bandits ${ }^{25}$ A Dr. John B. Porter, stationed in Monterey, Mexico, ran through his supply of drugs while awaiting a new shipment:

\begin{abstract}
So long as our quinine held out, there was no difficulty in managing the fevers,...pulv. cinchona did very well as long as it lasted, but this gave out, and we then resorted to serpentaria Virginiana and other bitters. When these gave out, we took to sulphate of zinc and myrrh, sometimes with, and sometimes without opium...But the sulphate of zinc gave out, and I was obliged to resort, very unwillingly, to the use of arsenic...Fortunately, the opening of communication with the depots at Camargo and Matamoros, and the arrival of a supply of quinine and other medicines and stores, rendered it unnecessary to continue the use of a dangerous remedy 26
\end{abstract}

Clearly, the army doctors had to be extremely resourceful, as it was uncertain whether they would have the drugs necessary to treat their patients. Army doctors had very little control over the quality of care they gave to soldiers when the army did not supply them with medicines or the means to run sanitary facilities. One doctor noted that, "[o]f all places I ever undertook to give medicine this [the warfront] was the worst. No one to nurse - not a spoon to give medicine with, hardly a tin cup to be found - not a scrap of cloth to make even a mustard plaster.' 27 The doctors' lack of necessary medical supplies can be traced directly back to a lack of funding by Congress.

Even when the army doctors made specific requests for medicines, they often could not obtain what they needed to treat patients. Army officers were constrained by small budgets, so rationed out available drugs in small amounts. One doctor described his experience with requesting medicines he needed for his patients:

\footnotetext{
${ }^{25}$ Santa Anna's Greatest Weapon at 120. Doctors in the Mexican War carried medicines such as quinine, calomel, laudanum, tincture of cayem pepper, spirits of camphor, essence of peppermint, and Hoffman's anodyne. See Soldiering, Suffering, and Dying at 297. The article notes that a full list of medicines Mexican War doctors carried is available at "Claim of Dr. A. Wislezenus for medical supply payment," H.R. Rep. No. 30-404, at 3-4.

${ }^{27}$ Lacrimosa at 36.
} 
"I found the stock of medicines exceedingly scanty - the assortment very poor...the government had not given us half medicines enough, and nothing like a full assortment. I wrote for Cay[e]nne pepper, syrup of squills, ginger, sage, and some other articles which they had not furnished at all. They did not send them...I had a talk afterwards with Dr. McCormick who told me that if he could, he would allow all the articles, that he knew they were necessary. He advised me to get more quinine and treat those cases with large doses. We went to Dr. Lawson (the surgeon Genl.) - Dr. McCormick said that I ought to have some more quinine at least. He hemmed and hawed and replied - "Well, well, let him have an ounce." Then Dr. told him that I wanted half a dozen ounces - The Old surgeon Genl. paused and said, "Well, let him have it." As I walked off I thought he would rather save five dollars for the government than save a poor Soldier's life.'28

If statements such as these reached the American public, Congress would face a lot of angry constituents. Valuing the bottom line over soldiers' lives was not the image that the government wanted to convey. The flowery language used in the Committee Report to describe the bravery of the troops demonstrated that Congress wanted to be viewed as strongly supportive of the soldiers who fought for America ${ }^{29}$ In its report, the Committee also referred to Congress's duty to protect its soldiers-failing to provide adequate funds for medical supplies was surely not a fulfillment of that duty 30

To exacerbate matters further, there were a large number of unqualified people providing medical treatment to troops during the Mexican War. There is historical dispute over whether the army doctors themselves were well- or poorly- qualified 31 The army doctors did have to pass a fairly rigorous exam before being hired, and the high failure rate for the exam likely indicates that the exam was successful at weeding out the worst physicians ${ }^{32}$ However, soldiers received medical treatment from a large number of people who did not have to pass the entrance exam. In Vera Cruz, for instance, there were not enough army doctors available

\footnotetext{
${ }^{29}$ See supra note 7 for the relevant text of the Committee Report. See also, infra p. 36 for a discussion of the Committee's appeal to Congress' patriotism.

${ }^{30}$ See supra note 7 .

${ }^{31}$ See Expansionism and Conflict at 191. For a discussion of medical education at the time of the Mexican War, see infra pp. 17-19, which describe the low standards many medical schools had for both admission and graduation.

${ }^{32}$ Army of Manifest Destiny at 55.
} 
to treat the number of sick soldiers. To remedy this, the army recruited "mere hacks from the streets of New Orleans or from the civilian populace of Veracruz itself." 33 The assistants to the army doctors, such as orderlies and nurses, were even less competent. Most often, the doctors pulled their assistants from among the soldiers ${ }^{34}$ The soldiers that the commanding officers were willing to spare for medical duty were usually the most incompetent or the most insubordinate ${ }^{35}$ A Dr. Love described his experience with the soldiers he asked to assist him:

When I came to see the patients, the nurses to whom I had given the directions were not to be found - I could not tell how the patient rested - what medicine he had taken, or in fact anything definite about him - the nurses generally were ignorant about giving medicine - Many of the menial duties I performed myself or had to let them go undone 36

With the few army doctors left to do everything on their own, it is small wonder poor medical treatment occurred. As Love's commentary makes clear, not only were the doctors unaided by assistants, but their work was often undermined. Clearly, there was a need for additional medical personnel, which greater funding could have provided.

\section{The Primitive State of Medicine During the Mexican War}

Medical science was still at quite a primitive level at the time of the Mexican War, and remained so even

\footnotetext{
${ }^{33}$ James M. McCaffrey, "Surrounded by Dangers of All Kinds: The Mexican War Letters of Lieutenant Theodore Laidley 64 (1997) [hereinafter Surrounded by Dangers].

${ }^{34} I d$.

${ }^{35} I d$.
} 
through the Civil War ${ }^{37}$ Indeed, as discussed in the next chapter, almost all the medicines that the doctors were using to treat disease have since been removed from the United States Pharmacopoeia because of their uselessness in treating disease ${ }^{38} \mathrm{In}$ this section, I argue that the unadvanced state of medicine, in addition to the poor living conditions created by Congressional underfunding, contributed much more to the number of American Mexican War deaths than any adulterated drugs did.

Conditions in Mexico caused many diseases amongst the American troops, but none was as feared as yellow fever, or "yellow jack." 39 Worry about the disease determined military strategy in many instances, including General Winfield Scott's decision to delay the occupation of Vera Cruz until the yellow fever season had passed ${ }^{40}$ Yellow jack was "an extremely infectious disease...characterized by high temperature, chills, headache, and pain in the arms, legs, and back, vomiting, and constipation." 41 As the disease progressed, there was "reduced excretion of bile, with consequent yellowing of the skin" (hence the name "yellow" fever), followed by "internal hemorrhaging [that] cause[d] blood in the vomit." ${ }_{42}^{2}$ Thediseasewasoftenfatal. 43 At the time of the Mexican War, no one was certain what caused yellow fever, or how it was transmitted, so the army doctors tried to prevent it by telling troops to do everything from avoiding overindulgence in food and

\footnotetext{
${ }^{37}$ See Expansionism and Conflict at 191-192.

${ }^{38}$ See infra pp. 19-20 for additional discussion on the topic.

${ }^{39}$ Yellow jack was not the only disease suffered by American troops-it was not even the greatest killer. Soldiers suffered and died from diarrhea, dysentery, catarrh, small-pox, and cholera as well. See Soldiering, Suffering, and Dying at 286. Additional diseases that plagued the troops were typhoid fever, measles, mumps, tuberculosis, and dysentery. See Expansionism and Conflict at 190-191.

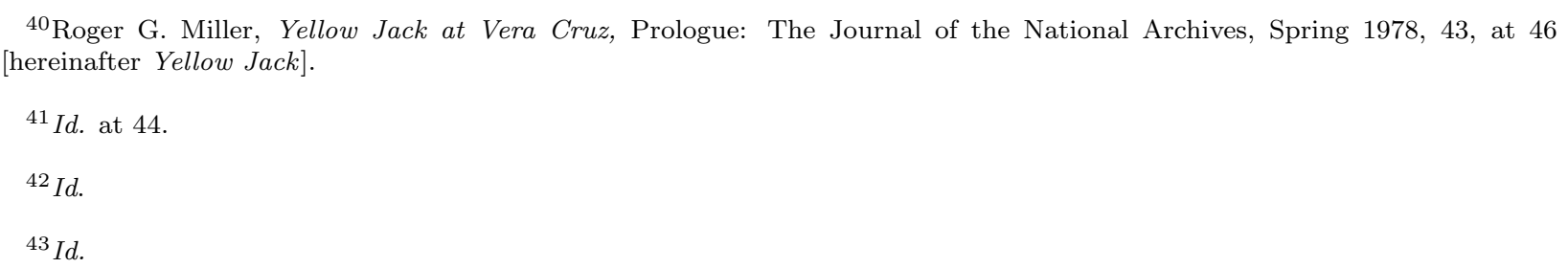


drink to staying out of the sun. ${ }^{44}$ A common belief was that the disease was transmitted from harmful vapors from decaying animal or vegetable matter, or the "miasmas" of a swampy climate ${ }^{45}$ The medical community did not discover until years later that the disease was actually transmitted by mosquitoes ${ }^{46}$ Quinine was the drug of choice to treat yellow fever, and it was most likely adulterated quinine that Congress latched onto as a reason for the Import Drugs Act. The army doctors "put their entire faith in treating yellow fever victims with quinine, and went so far as to claim that if the drug failed, the patient might as well have his coffin prepared." 47 A suspected yellow fever patient would receive a warm mustard bath, heavy doses of quinine, mustard plasters, and was sometimes bled through the use of leeches or local cupping ${ }^{48}$ In later stages of the disease, some physicians prescribed calomel (mercury chloride) to reduce nausea and vomiting 4 Though the physicians of the time did not know it, quinine did not have any effect on yellow fever 50 Thus, the "herculean doses" that convinced Congress that the drug must have been adulterated were a false clue. Even quinine of the highest quality and 100 percent strength would have failed to cure these soldiers. For Congress and the medical profession, however, the adulteration of quinine provided a palatable reason for its ineffectiveness. "Cold plague" was another camp disease that foiled doctors' expectations. Later suspected to be a type of meningitis, the disease did not respond to any of the medical treatments doctors threw at it $\sqrt[51]{4}$ Dr. Love wrote of his frustration in treating the ailment: "I invoked the aid of all I had learned from books or medical 
teachers, but found it unavailing. I used depletion, emetics and cathartics in vain. Sometimes large doses of quinine seemed indispensable, but these were injurious instead of beneficial." ${ }^{52}$ Every skill that medicine could teach Dr. Love was useless in his fight against this disease; he calculated that of the original 885 members of the 2d Mississippi Rifles, 97 died from the "cold plague," while 70 total died from all other diseases combined ${ }^{53}$ Medical knowledge of the time in many cases could not help doctors help their patients. The high mortality rate from disease was also caused by the soldiers' own actions and the lack of medical knowledge regarding sanitation. Doctors used the same medical instruments on multiple patients without any sterilization between patients ${ }^{54}$ The soldiers, however, created conditions of filth within the camps for which the government cannot be blamed. The United States Army fighting in the Mexican War was made up of volunteers and "regulars." "Regulars" belonged to the army before the war began, and were used to living in camp conditions. The volunteers enlisted after the start of the war, and had not yet learned how to live healthily in army camps. This difference was borne out by the substantially higher death rate for volunteers ${ }^{55}$ With many of them living away from home for the first time, the volunteers exhibited "an almost total disregard for their own cleanliness." 56 One soldier wrote home from Vera Cruz that "sickness of some kinds, fevers or the disease of the country, is pretty common and becoming more so every day. The volunteers not knowing how to take care of them, thus suffer the most and deaths among them are becoming more common." "57 The volunteers were often too lazy to obtain their drinking water upstream from 
where they urinated, defecated, or bathed, which resulted in epidemics of cholera and dysentery within the camps $\sqrt{58}$ One army doctor wrote that he treated many patients "who probably have not washed their persons for months, and who for weeks have not changed their underclothes, and who are not only filthy but covered with vermin.' 59

\section{Political Ramifications of the High Number of Soldier Deaths}

News of such horrific camp conditions and the poor medical care provided to soldiers stood to enrage any member of the American public - especially members of the public whose father, son, husband, or brother had lost his life to disease in the war. Letters home from soldiers were the most descriptive of the army's plight: "the people of the States have no idea of the amount of sickness and deaths there are here in the Army - arising from imprudence and exposure. $\sqrt{60}$ The potential political consequences for needless deaths were high. They were even higher when many of the deaths were caused by Congressional failure to provide necessary resources to the soldiers. Congress had no power over the state of medical science at the time, but it could control the quality of food and clothing its soldiers received, as well as the number of doctors and the quantity of medical supplies it made available. Congress controlled the purse-strings of the military, and the tighter it held them, the worse conditions were for the soldiers. As Congress was also in the position of having to justify the need for fighting the war, the pressure was on to explain why so many soldiers had

\footnotetext{
${ }^{58}$ Santa Anna's Greatest Weapon at 112-113.

${ }^{59}$ Id. at 113 (citing "Report of Dr. R.S. Satterlee", 5 July 1847, in Harvey E. Brown, The Medical Department of the United States Army from 1775 to 1873 (Washington, DC: Surgeon-General's Office, 1873) 187.)

${ }^{60}$ Surrounded by Dangers at 114.
} 
$\operatorname{died} 61$

Against this backdrop, Congress passed the Import Drugs Act. With one sentence, the House Report neatly blamed the vast number of war deaths from disease on foreign adulterated drugs. According to the Committee, "the adulteration of the medicines used... explains the lamentable mortality attendant upon our troops.' ${ }^{62}$ Yet, as this chapter demonstrates, adulterated medicines do not explain the high mortality rate of American troops: Congressional underfunding and primitive medical care do. Citing foreign adulterated drugs as the cause of the high mortality rate allowed Congress to shift all blame from itself and army doctors. In the end, Congress found it much better to blame a foreign source for unnecessary deaths than to accept the blame itself.

\footnotetext{
${ }^{61}$ For a discussion of how the Mexican War split the country, see generally, North America Divided: War with Mexico, 1846-1848 (Seymour V. Connor and Odie B. Faulk eds. 1971).

${ }^{62}$ H.R. Rep. No. 30-664, at 20.
} 


\section{Chapter 2:}

\section{The Professional Health Organizations}

\section{and the Problem of Adulterated Drugs}

In the 1840 's, the medical community of doctors and pharmacists were united in a fight against the adulteration of drugs. Adulterated drugs posed a problem for these professions because they had the potential to damage reputations - if the drug a doctor gave a patient proved useless against illness, the patient would have no faith in the doctor. As the traditional (allopathic) practice of medicine was competing against a number of strong alternative forms of medicine, maintaining a strong professional reputation was important. Both the medical and pharmacy professions took concrete actions to fight adulterated drugs. In the end, however, the primitive state of medical and pharmaceutical sciences may have been more to blame for the professions' poor reputations than any adulterated drugs were.

\section{Problems of the Traditional Health Professions}

During the 1840s, "the American medical profession was experiencing not only a diminished public confidence but also doubts within itself." 63 In the face of these doubts, physicians from around the country joined together

\footnotetext{
${ }^{63}$ Lester S. King, Transformations in American Medicine: from Benjamin Rush to William Osler, 195 (1991) [hereinafter Transformations in Medicine].
} 
with the hope of strengthening their profession ${ }^{64}$ Many physicians felt that the state of medical education was hindering more than helping the profession. Thus, one of the first things on the agenda of the American Medical Association (the "AMA") was the improvement of medical education. At its organizational meeting in May, 1846, two of the proposals presented dealt specifically with improving medical education. The first proposal noted, "that it is desirable that a uniform and elevated standard of requirements for the degree of M.D. should be adopted by all the medical schools in the United States." 65 The second urged "that it is desirable that young men, before being received as students of medicine should have acquired a suitable preliminary education. ${ }^{66}$ At the first annual meeting of the American Medical Association, the convention voted to recommend that men could not be accepted as medical students unless there was evidence that they "[we]re of good moral character" and had knowledge of subjects such as English, philosophy, basic math (including geometry and algebra), and enough mastery of Latin and Greek so that they could understand the technical language of medicine ${ }^{67}$ This resolution was adopted over protest that this would prevent poor, yet smart, men from becoming doctors; the protest was defeated by the argument that there were free public schools available so that all could master these basic subjects ${ }^{68}$ It was quite clear to almost everyone that medical education needed improvement. Indeed, "few states had any licensing requirements, and the majority of practicing physicians never graduated from medical school." 69 Medical schools required students to complete two terms of lectures, but many students were able to complete this requirement despite starting

\footnotetext{
${ }^{64}$ The American Medical Association was founded in 1846, and held its first Annual Meeting in May, 1848. See generally, Morris Fishbein, History of the American Medical Association (1947) [hereinafter History of the AMA].

${ }^{65}$ History of the $A M A$ at 25.

${ }^{66} I d$.

${ }^{67} I d$. at 28.

${ }^{68} I d$. at $28-29$.

${ }^{69}$ Expansionism and Conflict, at 191.
} 
the term late or failing to attend all the classes ${ }^{70}$ Students may have been such poor attendees of their classes because the two lecture terms they had to complete offered the identical set of lectures - not further coursework ${ }^{71}$ The final exams at the medical schools were not necessarily difficult to pass ${ }^{72}$ Indeed, in order to fund their schools through tuition moneys, the medical schools sought to attract students "by shortening of the curriculum and by the establishment of easy terms of graduation." 73 The most productive part of a medical education in the 1840's was a student's apprenticeship with a practicing doctor. In the first half of the apprenticeship, the student would study "anatomy, chemistry, botany, physiology, drugs and their actions, pharmacy, and clinical medicine."74 The student would assist the doctor with small tasks such as filling prescriptions, bloodletting, or dressing wounds ${ }^{75}$ in the second half of the apprenticeship, the student would go with the physician on patient calls, or assist in surgery ${ }^{76}$ At the conclusion of this, the student became certified to practice medicine.

The fact that under such a system practically anyone could become a doctor-regardless of intellect or skill — did much to harm the reputations of doctors. Also damaging to their reputations, however, was the fact that most of the time, their advice and prescriptions simply did not work. It was extremely important

\footnotetext{
${ }^{70}$ The length of a term was generally sixteen weeks, though some schools reduced it to thirteen. See History of the AMA, at 21.

${ }^{71} I d$

${ }^{72}$ Army of Manifest Destiny, at 54. One doctor said that anyone could pass the exam as long as they had paid their teachers. $I d$.

${ }^{73}$ History of the AMA at 21.

${ }^{74}$ Army of Manifest Destiny, at 54.

${ }^{75} \mathrm{Id}$.

${ }^{76} I d$.
} 
to a physician's reputation that he actually was able to heal people. Unfortunately, the arsenal of medicines available to physicians in the 1840's was not very powerful. Of all the drugs appearing in the U.S. Pharmacopoeia at the time, less than a dozen are considered "reliable and effective pharmaceutical preparations" by today's standards 77 Drugs still considered to be effective include quinine, morphine, digitalis, diphtheria antitoxin, aspirin, and ether ${ }^{78}$ The rest of the two hundred or so drugs on the list have either no effect or give only a small benefit 79 Of course, the doctors of the time had not way of knowing that the drugs they had been taught to use were virtually worthless. But, this fact surely did not improve their rate of success in treating patients.

In the 1840's, mainstream medicine was also receiving competition from sects such as homeopathy, Thomsonianism, and hydropathy ${ }^{80}$ These schools of medicine actively went after patients of allopathic physicians, and indeed, "regular physicians as a class did not have much better therapeutic results than did [the doctors following untraditional methods]. ${ }^{81}$ In addition to the poor cure rates of allopathic physicians, the public viewed the remedies of traditional medicine as extreme, especially bloodletting and the "heroic draughts" administered to patients. ers." ${ }^{82}$ As sectarian practitioners gained patients and believers, allopathic physicians lost them. This was hard for the allopathic physicians to swallow, as they were losing not only their reputations, but also the income these patients represented 83 Perhaps in response to this loss of business,

\footnotetext{
${ }^{77}$ Peter Temin, Taking Your Medicine: Drug Regulation in the United States 24 (1980) [hereinafter Taking Your Medicine]. For more information on the U.S. Pharmacopoeia, see infra note 191.

${ }^{78} I d$. at 24.

${ }^{79} I d$.

${ }^{80}$ See generally, Lester S. King, American Medicine Comes of Age: 1840-1920, 9-12 (1983).

${ }^{81}$ Transformations in Medicine, at 195.

${ }^{82}$ Transformations in Medicine, at 196.

${ }^{83}$ Id.at 195.
} 
the Committee on Medical Education had decided by the first annual meeting of the AMA that the United States had too many doctors. To remedy this, it suggested that private physicians taking apprentices should be more selective in choosing their students ${ }^{84}$ The Committee blamed the increased incidence of "quackery and charlatanism" on the overabundance of doctors, and saw limiting access to the profession as a solution to this problem ${ }^{85}$ Decreasing the number of doctors and limiting admittance to the profession would have the effect of increasing its prestige. It would also make access to medical treatment a scarcer resource, and allow doctors to charge more for their services, much like professions such as lawyers and accountants are able to.

\section{The Threat of Adulterated Drugs}

With all of these pre-existing threats to its reputation, the medical profession certainly did not need the reputational damage that adulterated drugs promised to inflict. In the 1840's, establishing a strong reputation for the vocation was essential, and a strong reputation would be built only on success in treatment. Adulterated drugs posed a great threat to the reputation of the medical profession: if patients did not recover from their illnesses because of inert drugs - or worse, were made even sicker by a contaminant within a drug - the prescribing physicians would be seen as incompetent. A letter to the editor of The Lancet, a prominent London medical journal spelled out this fear: "it is still more severe upon the physician or surgeon, who prescribes an important remedy, upon the success of which his reputation may depend, and whose

\footnotetext{
${ }^{84}$ History of the $A M A$, at 45.

${ }^{85}$ Id.at 46 .
} 
efforts are foiled by the substitution of something useless, or even injurious." $86 \quad$ Prescribing or selling adulterated drugs could certainly create a tainted reputation. As described earlier, such a poor reputation harmed physicians economically as well, as failure by traditional practitioners could drive patients to seek cures from nontraditional doctors and "quacks." Fewer patients yielded fewer fees for doctors. Thus, it was vital to both pharmacists and doctors that they be respected. Indeed, within the Code of Ethics Adopted by the Philadelphia College of Pharmacy (the "Ethics Code"), apothecaries were told to correct errors made by physicians in their prescriptions, "if possible, without knowledge of the patient, so that the physician may be screened from censure." 87 This code indicated an attitude of mutual protection among the health professions, rather than a competitiveness - whether this attitude was better for the patients served is less clear ${ }^{88}$

\section{The Professional Organizations Take Action}

Thus, adulterated drugs posed a substantial problem to the traditional health professions, and as the professional health organizations took shape, they looked for ways to solve the problem. The Philadelphia College of Pharmacy, a well-respected professional organization, attacked the problem through its Ethics Code. Under the Ethics Code, apothecaries were forbidden from intentionally selling "impure drugs or medicines, from

\footnotetext{
${ }^{86}$ A Mortar, Mr. Mortar on the Adulteration of Drugs to the editor of The Lancet, The Lancet, Feb. 8, 1851 at 172.

${ }^{87}$ Code of Ethics Adopted by the Philadelphia College of Pharmacy, $5^{\text {th }}$ Tenet (emphasis added) [hereinafter Ethics Code].

${ }^{88}$ There was much greater overlap between the professions than there is today, so it is unsurprising that the groups united here. For instance, prescriptions were not nearly as restrictive as they are today. A patient did not need to go to a doctor to get a prescription for a certain drug - he could go directly to the pharmacist or apothecary, who gave him whatever drug he asked for. Patients could also obtain drugs by purchasing them directly from doctors, many of whom sold drugs to patients instead of writing a prescription for a druggist or apothecary to fill. Thus, the lines between pharmacists and physicians were unclear, and patients had practically unfettered access to any drug they chose. See Taking Your Medicine at 23.
} 
motives of competition, or desire of gain, when pure articles of the same kind may be obtained." 89 The full ethical tenet read:

$7^{\text {th }}$. As the apothecary should be able to distinguish between good and bad drugs, in most cases, and as the substitution of a weak or inert drug for an active one, may, negatively, be productive of serious consequences - we hold that the intentional sale of impure drugs or medicines, from motives of competition, or desire of gain, when pure articles of the same kind may be obtained, is highly culpable, and that it is the duty of every honest apothecary or druggist to expose all such fraudulent acts as may come to his knowledge. But in reference to those drugs which cannot be obtained in a state of purity, he should, as occasion offers, keep physicians informed of their quality, that they may be governed accordingly.

Through this ethical tenet, the Philadelphia College of Pharmacy sought to resolve the problem of providing adulterated drugs to the public by placing the burden of prevention on the apothecaries, rather than on import inspectors, as the Import Drugs Act later did. The ethical tenet focused on the end of the chain of distribution of an adulterated drug, rather than the beginning. It also addressed the problem of domestic adulterated drugs as well as foreign ones, since it did not draw a distinction between the two in its sales prohibition 90 In this way, Philadelphia code provided broader protection to the public than the Import Drugs Act did because it could prevent all adulterated drugs - not just drugs imported after passage of the Act-from reaching patients. Even adulterated drugs that slipped past federal inspectors could be intercepted by the apothecaries - thereby saving the public from their harmful effects. Through this ethical tenet, the profession of pharmacy indicated its recognition of the problem of adulterated drugs, and that the profession could play a role in resolving the problem.

\footnotetext{
${ }^{89}$ Ethics Code, at $7^{\text {th }}$ Tenet.

${ }^{90}$ See infra pp. $42-43$ for a discussion of the decision not to address domestic drug adulteration through the Import Drugs
} Act. 
The Ethics Code was an incomplete solution to the problem, however, and could not be counted on to prevent adulterated drugs from reaching the public. First, it was unclear what sort of punishment apothecaries faced by violating this tenet and intentionally selling adulterated drugs. Second, it was unclear how violations of the tenet would be discovered, as success of the tenet was dependent upon self-policing by apothecaries or upon observant and vocal customers. For these reasons, there was little incentive for individual apothecaries to follow the code. Individual apothecaries may have realized that, in the aggregate, following the tenet would be better for the profession, but individually, an apothecary could make money more quickly by selling adulterated drugs. Finally, the tenet was worded so that it would be very difficult to violate. It focused on the intention of the selling apothecary, which greatly decreased the amount of adulterated drugs that would be prevented from reaching the public. The apothecary would be guilty of violating the code only if he intentionally sold the impure drug from motives of competition or desire of gain. Moreover, to violate the tenet also required that pure drugs of the same type had to be available to the apothecary. Thus, an apothecary violated this tenet only if he satisfied all of the conditions mentioned: 1) intentional selling; 2) of a known unpure drug; 3) with the intent of making a profit or competing economically; 4) when there were pure drugs of the same type available to him. According to the language of the statute, if even one of these conditions were not met, the apothecary would not be in violation of the ethics code, and it would be acceptable for the impure drug to reach the public. Therefore, the ethical tenet did not provide sufficient incentive for apothecaries to abide by it because 1) it was difficult to actually violate it; 2) no punishment for violation was specified; and 3) no mechanism was in place to identify violations.

An ethics tenet promulgated by apothecaries - even if abided by - would not reach the adulterated drugs dispensed directly by physicians. Thus, the reputations of doctors were still threatened by the problem 
of adulterated drugs. The American Medical Association (the "AMA") identified adulterated drugs as a problem at its very first annual meeting on May 2, 1848. One of the resolutions presented at this meeting was that the AMA lobby Congress to pass "a law against the importation and sale of adulterated, deteriorated, and misnames drugs."'91 The AMA's lobbying took the form of submitting a memorial to Congress urging it to appoint inspectors at major ports of entry to the U.S. to examine imported drugs and medicines ${ }^{92}$ The memorial read:

The memorial of the American Medical Association, consisting of delegates from the several States in the Union, at their annual meeting in Baltimore, assembled May, 1848, respectfully represent:

That it has become notorious among druggists, apothecaries and physicians that, of late, important drugs and medicines are specially adulterated in foreign countries, for sale in this, and pass daily through the custom house, to be disseminated by ignorant and unprincipled dealers, to the great detriment of our citizens.

That, believing Congress possess the power to enact laws to prevent the evils complained of, by subjecting all drugs and medicines to the inspection of persons duly qualified, whose duty it shall be to ascertain their real value, character and strength, and to keep such records as will guard the honest dealer against imposition, your memorialists, therefore, ask your honorable body that a law be enacted, embracing the appointment of a proper inspector, at each chief port of entry, whose duty it shall be to examine all imported drugs and medicines, and to keep a record of such inspections, including the names of the parties, which shall be open for consultation to druggists and apothecaries and others concerned' or to adopt such other measures as, in your wisdom, you may deem best adapted to prevent the evils complained of; and your petitioners will ever pray.

Signed, Alexander H. Stephens, of New York, president; Alfred Stille, of Pennsylvania, and H.J. Bowditch, of Boston, secretaries ${ }^{93}$

\footnotetext{
${ }^{91}$ Minutes of the First Annual Meeting of the American Medical Association, Baltimore MD, May 2, 1848.

${ }^{92}$ F.J.Blasigame, American Medical Association, 1846-1958 Digest of Official Actions of the American Medical Association 177 [hereinafter AMA Digest]. A "memorial" was the term for a petition or prayer to Congress to take some sort of action.
} 
The AMA's support of the Import Drugs Act demonstrates the recognition by the group that it was better to act to correct the problem of drug adulteration in small steps rather than not at all. The AMA could have waited to give its support to a law that would have gone after all adulterated drugs, rather than simply the imported ones.

Other actions by the AMA indicated that it viewed regulating only imported drugs as insufficient. In May 1849, a year after the passage of the Import Drug Act, the AMA appointed two delegates from each U.S. state "to note facts on adulteration of drugs," and "commended the Philadelphia College of Pharmacy on its intention to publish "instructions for detecting adulterations in medicine." ${ }^{94}$ In May 1850, the AMA House of Delegates passed resolutions recommending: 1) that states appoint boards of examiner who would examine drugs sold in stores; 2) that druggists work against "fabrication and sale of inferior and adulterated drugs"; and 3) that the AMA appoint a committee of state representatives to "collect information on spurious and adulterated drugs.' ${ }^{95}$ Finally, in May 1853, the House of Delegates "approved appointment of a committee 'to report on the best mode of preventing the domestic adulteration of drugs." "96 This demonstrated clear acknowledgment that adulteration of drugs was not merely a problem of imports, but was a problem in the domestic market as well.

\footnotetext{
${ }^{94}$ AMA Digest, at 177 .

${ }^{95}$ Id. at $177-178$.

${ }^{96}$ Id. at 178 .
} 
The health professions' fight against adulterated drugs represented much more than concern for public health and safety. Certainly, many doctors and pharmacists were worried about the risks that adulterated drugs posed for their patients. However, adulterated drugs posed a concurrent risk to the reputation, and perhaps even the existence, of the professions themselves. At a time when traditional physicians were fighting to convince patients that they could cure them, adulterated drugs acted as an additional challenge. Traditional physicians believed in the efficacy of their treatments, and adulterated drugs tended to undermine this efficacy. 


\title{
Chapter 3:
}

\section{The Proposal and Passage of the Import Drugs Act}

\begin{abstract}
"The cool-blooded, deliberate, studied, and fatal deception practised in articles designed for the relief of suffering and disease, can admit of no palliation-can find no excuse.'?97
\end{abstract}

Congress began considering the issue of adulterated drugs in January, $1848{ }^{98}$ To analyze the issue more completely, it appointed a Select Committee on the Importation of Drugs (the "Committee") to hold hearings and conduct research on the issue. The Committee was made up of Congressmen with experience in the medical field, and was headed by Representative Thomas O. Edwards of Ohio ${ }^{99}$ Edwards was a wellrespected medical doctor who took his duties on the Committee very seriously. After quite a bit of research, the Committee presented House Report 664 (the "Committee Report") to Congress on June 2, 1848 , and advocated strongly for the passage of House Bill 524, which was to become the Import Drugs Act.

In this chapter, I look at the legislative history of the Import Drugs Act and the social conditions that prompted it. First, I describe the problem of adulteration in imported drugs and the reasons why foreign

\footnotetext{
${ }^{97}$ H.R. Rep. No. 30-664, at 23 (1848).

${ }^{98}$ The House and Senate began receiving petitions on the matter of adulterated drugs beginning in January, 1848. See e.g., Journal of the Senate for 1848, at 140.

${ }^{99}$ See H.R. Rep. No. 30-664, at 1.
} 
drug manufacturers were shipping adulterated products to the United States. I then look briefly at the communities that turned Congress's attention to the matter, and describe how the Committee determined that House Bill 524 was the best solution to the problem of adulterated drugs. I continue with a discussion of the policy reasons the Select Committee marshaled in support of the bill, and close with an analysis of the debate regarding the bill on the floors of the House and Senate.

\section{The Problem of Adulterations in Imported Drugs}

To demonstrate to Congress what exactly the problem was, the Select Committee catalogued a long list of common adulterations in imported drugs. The "blue mass pill," for example, which contained $33 \frac{1}{2}$ percent mercury when pure, was imported and sold with only $7 \frac{1}{2}$ percent mercury 100 The rest of the pill, according to the chemical analyses of a pharmacy professor, was made up of 27 percent clay, 16 percent water, 34 percent "soluble saccharine matters," 12 percent "insoluble organic matter," and trace percentages of coloring and sand 101 Sulphate of quinine, derived from Peruvian bark, was adulterated by being combined with chalk, plaster of Paris, and the salts of willow bark ${ }^{102}$ The Committee Report referred to instances of exporters removing the medicinal nature of a substance before exportation. For instance, before sending opium to America, foreign exporters would extract "the morphine or vital principle" from it ${ }^{103}$ Imports of scammony, another drug, "contain[ed] generally only about one-half the active principle of the genuine article." "104 The 
rest was "a worthless vegetable extract comingled with clay." ${ }^{105}$ Finally, deliberate adulteration was not the only problem with imported drugs. Poor shipping conditions often led to a product that was much deteriorated by age when it arrived in the United States ${ }^{106}$ Page after page of the Committee's report described how various common drugs were imported in adulterated or worthless states 107 The proportion of imported drugs that were adulterated also was of interest to the Committee. A Customs inspector from the Port of New York reported that prior to passage of the Act, "more than one half of many of the most important chemical and medicinal preparations, together with large quantities of crude drugs, come to us so much adulterated, or otherwise deteriorated, as to render them not only worthless as a medicine, but often dangerous." 108 This indicated to the Committee that the problem was incredibly widespread, and that action taken on this issue would affect a large amount of drugs. Imports of drugs were in the thousands and hundreds of thousands of pounds at the port of New York, and if over half of them were adulterated, an action by Congress here could be worthwhile 109 Imported drugs were adulterated in a variety of ways, but always with the motive of profit. The Committee was concerned that spurious drugs were being sold at higher prices than they were worth. Here, the economic concerns, rather than the safety, of the American people were persuasive to Congress. In its report, the Committee painted a horrific picture of "worm eaten and decayed" rhubarb, of opium mixed with "Spanish liquorice paste" and "infested with living worms," and of an imitation castor compound made up of "dried blood, gum ammoniac, and a little real castor." [110 After being purchased at American ports, these inferior products would be mixed with other substances to disguise 
their poor quality, before being sold to the general public ${ }^{111}$ What was emphasized along with the viscerally disturbing images of worms, was that the deteriorated rhubarb and impure opium were sold at prices that implied that they would have a medicinal effect $\mathrm{112}^{112}$ The Committee admitted that often the price charged for a deteriorated product would be less than that charged for a pure or fresh product, but still expressed outrage that such products could be sold at all, when the medicinal effect they would have would be minimal at best ${ }^{113}$ The treatment of the source of quinine presented another example of this economic adulteration. The Committee described how Peruvian bark "comes to us in large quantities entirely unfit for medicinal purposes." 114 The inferior bark "is eagerly bought up at auction sales by unprincipled drug dealers, and sent to the drug mills, where it is ground and powdered, the color, smell, and natural taste imitated, and afterwards sold to country dealers and others as a good article." $[115$ Good quality Peruvian bark commanded 30 to 40 cents per pound at its place of production, but the bark coming through the United States ports was invoiced at only 2 to 7 cents per pound because of its poor quality ${ }^{116}$ According to the Committee, even this low price was "justly...considered very dear."117

\footnotetext{
${ }^{111} I d$. at 5 .

${ }^{112}$ See e.g., id. at $4,6$.

${ }^{113}$ See e.g., id.

${ }^{114} I d$. at 4. Peruvian bark, also known as cinchona bark, or Jesuits' bark, is the source from which sulphate of quinine is derived. It grows wild only in the jungles of Peru, and became very valuable due to the limits placed o the supply when the Peruvian government prohibited exportation of the bark. Gradually, some of the trees were smuggled out of the country, and plantations of the trees were started in Sri Lanka and Java. See Alfred Burger, Understanding Medications, available at http://www.a1b2c3.com/drugs/gen001.htm.
}

${ }^{115}$ H.R. Rep. No. 30-664, at 4.

${ }^{116} I d$.

${ }^{117} I d$. 


\section{American Markets as Targets for Foreign Drug Manufacturers}

The fear that the United States was becoming the only market allowing the importation of adulterated drugs was one of the primary motivating factors of the Act. The Committee concluded that America "had become the grand mart and receptacle of all the refuse merchandise of [adulterated drugs], not only from the European warehouses, but from the whole Eastern world." ${ }^{118}$ In its report, the Committee made reference to the laws existing in Europe at the time that allowed the sale only of "genuine articles" of drugs and medicines ${ }^{119}$ In the view of the Select Committee, these laws had not stopped the production of the inferior drugs in Europe; rather, the European manufacturers now looked to the United States as the only market in which to sell their goods ${ }^{120}$ This conclusion was based on the increasing amount of European drug imports over "a long series of years." 121

Indeed, by 1848, a number of European nations had already passed laws regulating the quality of drugs that could be sold within their borders. As of 1803, France had a law requiring at least one annual inspection of pharmacies, wholesale druggists, and spicers ${ }^{122}$ nnspections were conducted by groups drawn from medical and pharmacy schools, or by doctors and pharmacists ${ }^{123} \mathrm{~A}$ member of the police force would accompany the inspector, and the group had the authority to seize inferior drugs and to impose sanctions ${ }^{124}$ France

\footnotetext{
${ }^{118}$ Id. at 3 .

${ }^{119} I d$.

${ }^{120}$ See id.

${ }^{121} I d$.

${ }^{122}$ Alex Berman, Drug Control in Nineteenth-Century France: Antecedents and Directions, in supra note 2.

${ }^{123}$ Id. at 9 .

${ }^{124} I d$.
} 
updated this legislation in 1851 when it passed a new law penalizing those who sold adulterated food or drugs 125 England also had laws preventing the sale of inferior drugs, which led the Committee to conclude that London was dumping its low quality drugs on the United States ${ }^{126}$ According to the report, the largest proportion of imported adulterated drugs came from England ${ }^{127}$ The report concluded that

it is but reasonable to suppose that large quantities of crude drugs, of a greatly deteriorated and inferior quality, must necessarily be constantly accumulating in [London's] warehouse, which, on account of the long existing laws of that country, cannot find a home market, and, in consequence, must either be destroyed or exported to some place where there is no law to prevent their introduction." 128

Thus, a sense of protecting United States citizens from the dangers threatened by the rest of the world, as well as a desire to have laws as modern as other leading countries, moved Congress to act here.

The Committee Report revealed that foreign sellers of drugs perceived an American demand for adulterated or inferior drugs ${ }^{129}$ Foreign drug manufacturers would ship several qualities of drugs to America, priced according to their varying degrees of purity and strength $\sqrt{130}$ The manufacturers explained this by saying that "they must accommodate the demands or lose sales,... as both qualities are ordered in large quantities from the United States - the genuine article, as they are given to understand, for the seaboard, and the adulterated for the western trade!" 131 This implied that customers on the "seaboard," or Eastern United States, were willing to pay more for their drugs to receive the genuine article, while those in the western parts of the country were willing to buy the lower quality drugs because of the lower price. The committee report linked

\footnotetext{
${ }^{125} I d$.

${ }^{126}$ H.R. Rep. No. 30-664, at 12 .

${ }^{127}$ Id.at 13 .

${ }^{129} I d$. at $6-7$.

${ }^{130}$ Id.

${ }^{131} I d$ at 7.
} 
the "excessive doses of medicine...prescribed, particularly in the south and west" to the "adulterated agents prepared expressly for "southern and western trade'." 132 The report spoke of "incredible quantities" of quinine being taken in the south and west, "portions of which, if pure, might well startle the eastern and northern practitioner, and used anywhere would endanger life."133 These large doses of quinine, the Committee Report claimed, were due not to differences in climate or disease, but to the inferior quality of the drug ${ }^{134}$ The American demand for adulterated or weak drugs may well have been stimulated by the sales representatives that foreign drug manufacturers sent to the United States to drum up business. The Committee noted with furor that diluted quinine was sold under the label of a well respected French drug manufacturer, but was actually produced in Belgium at an establishment whose "whole business...is to manufacture and dispose of base imitations of all the important foreign chemical and medicinal preparations." 135 The Committee was further incensed that the Belgian manufacturer had sent a salesperson to the United States to take orders for the products 136

Foreign catering to a domestic demand for spurious drugs was not the only problem for the Committee. It also took serious issue with the deceptive labeling of imported drugs. In addition to the quinine mentioned above, the Committee discussed inferior calomel being sold under "the name of some well known and deservedly popular manufacturing chemist." "137 The Committee expressed outrage on behalf of the consumer for being duped into buying a worthless product, but also on behalf of the honest manufacturer, whose good name was being exploited through the deception. With such deception going on, "the label and the mode of package

\footnotetext{
${ }^{132}$ H.R. Rep. No. 30-664, at 18.

${ }^{133}$ Id. at 18 .

${ }^{134} I d$

${ }^{135}$ Id. at 7 .

${ }^{136} \mathrm{Id}$. at $7-8$.

${ }^{137} \mathrm{Id}$. at $7-8$
} 
afford[ed] no security to the honest purchaser." $[138$ Thus, inserted into House Bill 524 was a requirement that all foreign drugs that traditionally came with labels had to be labeled with the name of the manufacturer and the place of production ${ }^{139}$ What the Committee thought this would accomplish was unclear, since the requirement still would not prevent a dishonest importer from putting the name of a reputable manufacturer on his label.

Though the Committee made much of the economic effect of adulteration on consumers, it quickly dismissed the economic effect that the bill could have on trade and commerce ${ }^{140}$ ndeed, there were no questions about the possible economic impact on trade even during the Congressional debate on the bill ${ }^{141}$ Though it acknowledged the argument that trade and commerce should be unrestricted, and that men "should be allowed to purchase... [according to] their tastes or interests," the Committee felt that the issue of adulterated drugs should be an exception to this rule ${ }^{142}$ In making its argument, the Committee distinguished medicines from other goods that were regularly traded freely ${ }^{143}$ For instance, if an article of clothing from abroad was defective because it lost its "gloss" or was not warm enough, it could be replaced with a more durable domestic item. Similarly, if a buyer got a headache from drinking imported alcohol, he could remedy the situation by not drinking at all ${ }^{144}$ Yet, with drugs, if the medicine was not of the requisite strength or purity, the user would run the risk of increased suffering or death ${ }^{145}$ According to the Committee, the risks

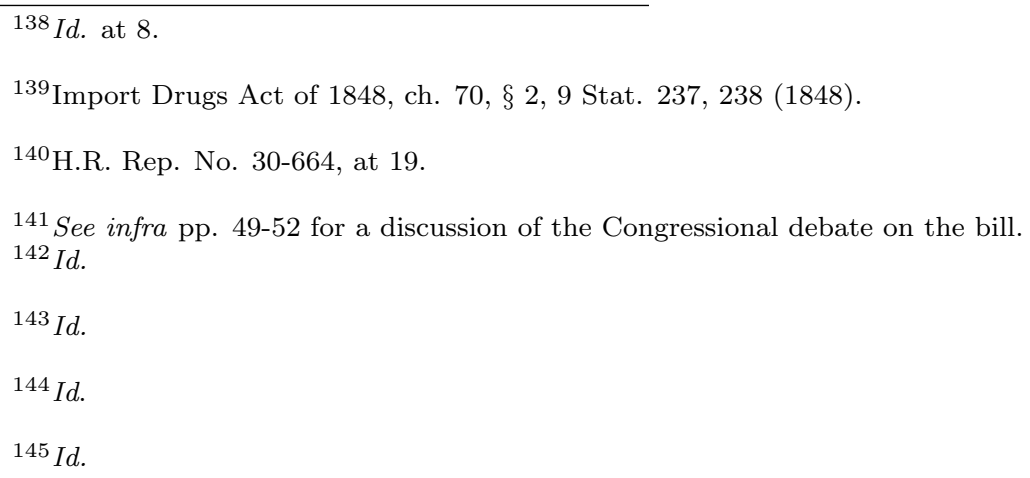


that a user of adulterated drugs runs were such that economic arguments were not enough to justify their importation.

\section{Support for Congressional Action against Importation of Adulter- ated Drugs}

The adulteration of quinine was one of the primary public triggers to proposal and consideration of the bill. As discussed in Chapter 1, the public feared that American soldiers fighting in the war with Mexico were being given adulterated drugs, especially adulterated quinine. The soldiers were reportedly being given "herculean portions" of medicines, which the Committee attributed to the weakness of the adulterated drugs ${ }^{146}$ Indeed, according to the Committee Report, the adulteration "accounts for and fully justifies these seemingly extravagant prescriptions, and also explains the lamentable mortality attendant upon our troops.' 147 The Committee appealed to the patriotism of the members of Congress by praising the valor of the American troops, and suggested that they owed the army a duty of protection from the harms of adulterated drugs ${ }^{148}$ As demonstrated in Chapter 1, this issue was more complicated than the Committee made it seem, as many factors caused the high mortality rate of American soldiers.

Further public support for House Bill 524 and its companion Senate Bill 200 came in the form of several memorials, or petitions, submitted by various pharmacy and medical organizations, lobbying for passage of the bill ${ }^{149}$ The Committee took the memorials and the expertise they represented very seriously. It discounted 
the possibility that any selfish motive was driving the medical profession to support this bill ${ }^{150}$ According to the Committee Report, "humanity, self-respect, and a just professional pride" had motivated the physicians to lobby for the bill 151 The Committee argued that the public tended to lose confidence in the medical profession when drugs - due to an adulterated or deteriorated nature - did not function as the physician predicted ${ }^{152}$ If the public did not trust physicians, they would be more open to "pretence and quackery" of pretenders ${ }^{153}$ Therefore, Congress needed to address the problem of adulterated drugs in order to 1) protect the good name of the medical profession; and 2) protect the public from being taken advantage of by "men whose qualifications give them no claim whatever to either confidence or respect."154

Congressional action on adulterated drugs was also endorsed by the Treasury Department in a May 25, 1848 letter to the Select Committee ${ }^{155}$ The Acting Secretary of the Treasury, McClintock Young, declared that "no doubt is entertained by this department that many valuable lives are sacrificed every year by the importation of adulterated and deteriorated drugs, and that the evil is increasing." 156 The Acting Secretary likened the bill to prevent the importation of adulterated drugs to a law already in effect that forbade the importation of "all indecent and obscene" images ${ }^{157}$ Under that 1842 Tariff Act, Customs officials seized and

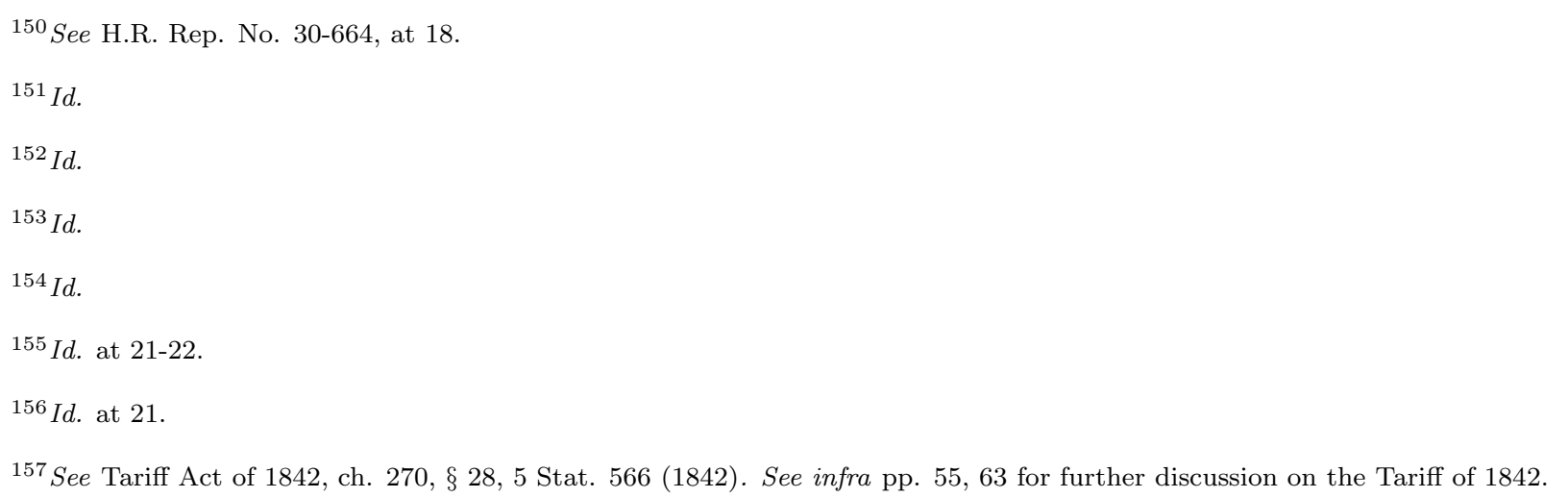


destroyed all such imported goods 158 That law was "designed to guard against the corruption of the public morals," while the proposed drug law was designed, according to the Acting Secretary of the Treasury, to preserve "the lives and health of the community." 159 The Acting Secretary felt that the bill before Congress would "diminish or suppress" the importation of adulterated drugs, and therefore the Department would "cheerfully and promptly cooperate" with such a law ${ }^{160}$ Notably, the Acting Secretary did not write that the bill would succeed in ending the importation of inferior drugs, but only that it would diminish or suppress the problem. The Committee did not comment on this language in its report to Congress.

\section{The Select Committee Attacks the Problem}

In evaluating the problem of adulterated drugs and possible solutions to it, the Committee relied heavily on the testimony of Dr. M.J. Bailey, a customs examiner from the New York Custom-House. Bailey had served as the examiner of drugs, medicines, and chemical preparations at the Port of New York since December 3, 1846 ${ }^{161}$ The Secretary of the Treasury asked him to investigate the issue of adulterated drugs for the Committee ${ }^{162}$ The Committee clearly thought highly of Bailey, and Bailey clearly thought highly of himself. The committee report noted that the country and the medical profession "are deeply indebted [to Bailey] for 
the firm and faithful stand he has taken in exposing these frauds." 163 Bailey offered his services even before the Committee summoned his aid, and in a letter to the Committee on April 29, 1848, he praised his own motives in fighting against adulterated drugs:

I have from the first, in aiding the college of pharmacy and my profession in their appeal, used the knowledge acquired in my present position with a single desire to advance the general good. Motives of self or pecuniary interest (had I listened to the prayers of those interested) would have prompted me to withhold from the public the facts I have willingly disseminated, in order that permanent benefit might result therefrom. Many an argument have I held with those who professed to think it no moral wrong, while it was more profitable to themselves to impose such worthless and dangerous trash upon the community as we complain of 164

Bailey's motives likely were noble in that he wanted to keep inferior drugs away from the public. However, he probably was also spurred by "motives of self or pecuniary interest," as he was soon appointed the special examiner for the Port of New York under the Import Drugs Act. Under the Act, the examiner for the Port of New York received a higher salary than the inspectors at all other ports, and Bailey's appointment very likely stemmed from his involvement in the passage of the Act 165 One of Bailey's tasks was to explain to the Committee how the Customs Service dealt with imported drugs at the time. He described to the Committee how Customs inspectors at all the ports had the narrow duty of checking imported cargo to see that it was priced fairly, and matched the invoice of the ship ${ }^{166}$ Under this scheme, Bailey, as examiner, was privy to all kinds of adulterated drugs coming through, yet could do nothing to stop their importation based on their adulteration. Bailey lamented that "as the law now is, I must pass all such dangerous and rascally imitations, if they are found to be charged at their full value, and...to be the article specified in the invoice. ${ }^{167}$ As part of his testimony, Bailey also made recommendations to Congress on how to stop

\footnotetext{
${ }^{163}$ H.R. Rep. No. 30-664, at 5.

${ }^{165}$ See Import Drugs Act, ch. 70, $\S 5,9$ Stat. at 238.

${ }^{166}$ H.R. Rep. No. 30-664, at 6.

${ }^{167} I d$.
} 
the importation of adulterated and deteriorated drugs. He asked for a law requiring that all imported drugs and medicines be examined by customs officials prior to their acceptance into port 168 Only if the drugs were found to be of good quality, strength, and purity would they be allowed to pass through Customs ${ }^{169}$ He also explained the difference between several types of Customs officials, so that Congress would know what kind of appointments to make for the people they chose to evaluate the drugs ${ }^{170}$ Bailey's testimony demonstrated to Congress that it would be a natural extension of the duties of Customs - who was already inspecting imported goods - to have its inspectors also evaluate the quality of imported drugs.

Congress also had to decide what to do with the drugs that were found to be adulterated by the Customs examiners. Its options were 1) an "increased duty on the adulterated article" or 2) "condemnation, re-exportation, or destruction" of the article ${ }^{171}$ The Committee decided against imposing a higher duty on adulterated drugs because doing so would still allow the dishonest shippers to make a profit ${ }^{172}$ The Committee supported this claim by positing the possible scenario of a foreign shipper who sought to import highly adulterated rhubarb that was worth virtually nothing medicinally 173 if Congress merely imposed a higher duty on the shipper, traffic in adulterated drugs would still occur because the shipper would be able to set a very low price on the rhubarb, pay the high duty on it, and then sell to an importer at a price that was both 1) lower than the importer would pay for good-quality rhubarb and 2) profitable to the shipper ${ }^{174}$ Thus,

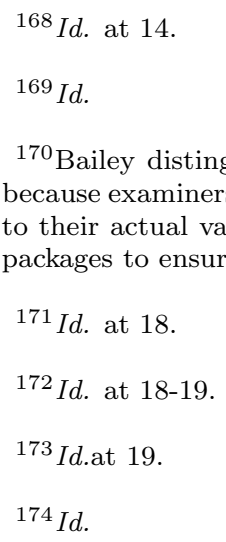


raising the duty "would be compounding with villainy." 175 For this reason, the Committee chose to prevent adulterated drugs from entering the United States by having Customs seize or re-export the goods.

The Committee was concerned with determining how and if a law prohibiting the importation of adulterated drugs would affect the domestic drug market. The Committee quizzed Dr. Bailey on whether "the domestic manufacturer [would] be induced...the more readily to the preparations of similar [adulterated] articles" if it prohibited the importation of adulterated drugs ${ }^{176}$ Bailey's response was that "by no means" would domestic drug producers be spurred to fill the void of adulterated drugs ${ }^{177}$ According to Bailey, once foreign adulterated drugs were removed from the market, the "regular trade" of drug purchasers and consumers would quickly identify any adulterated drugs as domestic and would trace them back to their source ${ }^{178} \mathrm{He}$ believed that once the domestic producers of adulterated drugs were revealed, the producers would suffer a loss of reputation, and would be driven out of business ${ }^{179} \mathrm{He}$ also recommended that Congress allow the states to enact their own laws to combat domestic drug adulteration 180

It seems strange by today's standards that Congress chose to focus only on foreign adulterated drugs and not on the domestic adulterated drug market. Feelings of nationalism and widespread xenophobia among Americans may have influenced Congress in this decision. Massive amounts of worthless patent medicines were being produced and sold within America at the time the Act was passed, yet the Committee did not make reference to this fact ${ }^{181}$ This willful blindness of the Committee Report may be linked to the pro-America 
attitude of the time, exemplified by the idea of "Manifest Destiny." The 1840's and 1850's were the era of westward expansion in the United States. The country had only just completed the Mexican War, which gained New Mexico and California, and in 1846, had acquired a portion of Oregon from Great Britain ${ }^{182}$ The United States was suspicious in general of Mexicans and other foreigners 183 The Committee manifested this xenophobic attitude in its report through its attribution of maliciousness to foreign shippers who chose to dump tainted products on America ${ }^{184}$ American insularism does not fully explain why Congress did not attack the problem of domestic adulterated drugs along with the foreign ones. Probably the main reason that Congress did not address the domestic drug market - though this is not mentioned in the legislative history - is that in 1848, Congress believed that regulating the domestic adulteration of foods and drugs was a matter for state and local governments to address. Testimony to the Committee counseled leaving the domestic problems to the States, who could choose for themselves whether or not to prevent the sale of adulterated drugs ${ }^{185}$ Even by 1879 , when national regulation of the safety of domestic foods and drugs was proposed through legislation, Congress did not feel it had the power or the mandate to regulate in this area ${ }^{186}$ Congress also needed to provide for due process concerns in designing the bill. The portion of the bill allowing an importer to ask for an objective reevaluation of his goods provided the necessary process ${ }^{187}$ This section of the bill was modeled on already-existing Customs regulations that allowed an importer to have his 1961).

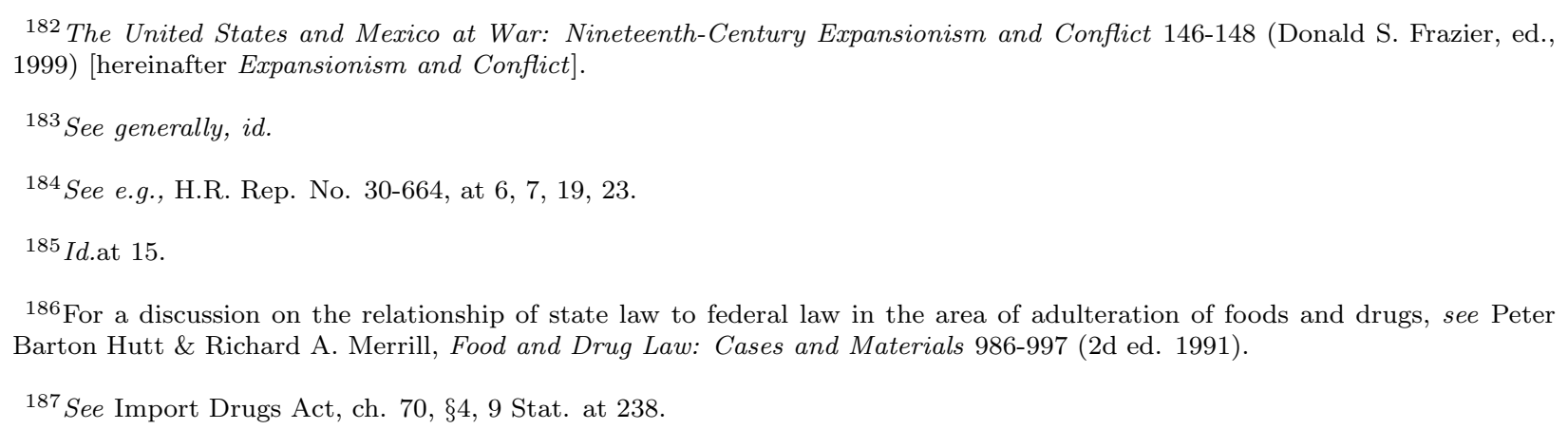


goods reappraised if he disagreed with their initial valuation ${ }^{188}$ Under the Customs system existing prior to the Import Drugs Act, the importer had to pay for the expense of reappraisement of the goods, and then "two disinterested merchants" would examine and revalue the goods 189 Under the Import Drugs Act, an analytical chemist from outside the Customs Service would examine the goods for adulteration if the foreign shipper challenged the conclusion of the special examiner ${ }^{190}$

The legislative history of the Act offers no hint as to why the drafters of the original bill chose to use the standards of several international pharmacopoeias, rather than simply the United States Pharmacopoeia. $\left[{ }^{191}\right.$ If the Committee had chosen the United States Pharmacopoeia as the only standard, the special examiners in the Customs Service would have had to master just that standard for the several hundred types of drugs that were imported each year ${ }^{192}$ Under the Act as passed, however, the special examiners also had to master the Edinburgh, London, French, and German pharmacopoeia standards for each drug ${ }^{193}$ One can only speculate as to why this decision was made. One possible reason is that Congress did not want to completely alienate its foreign partners in trade, so it chose to mediate the effects of the Import Drugs Act by using foreign as well as domestic standards for drug quality. Another possible reason is that Congress recognized that the 
field of medicine was an art as well as a science, and felt that the standards of other nations could be as good or better than the standards of the United States. Whatever the rationale, the Committee's choice to use multiple pharmacopoeia ensured that the job of special examiner would be extremely demanding.

\section{Policy Arguments Favoring Passage of the Bill}

The Committee appealed to several potent policy arguments in urging Congress to pass the legislation. Attempting to attract votes for the bill, the Committee alerted the members of Congress that they were also consumers of the very same drugs that were imported daily ${ }^{194}$ Realizing that the medicines they relied on to preserve the health of themselves and their families were worthless or even tainted may have prompted more than a few affirmative votes on the bill. The Committee report reminded Congress that "no one is exempt from attacks of disease," and that "soon or late all mankind need the aid of medicine."195 The drugs listed as routinely adulterated in the committee report (opium, quinine, blue mass bill, calomel, iodine, and several others) were just the drugs that most likely were regularly taken by the Congressmen and their families ${ }^{196}$ These were not obscure drugs, but ones that were readily available from any apothecary, with or without a prescription 197 As the Committee Report noted, "there are but few of us who have not stood beside the beds of sick friends, and watched with anxiety the professional attention of the physician; and we 
have staked our confidence and our all on the curative agents administered." $[198$ Congress and the public at large believed in the curative effect of medicines. In passing the Import Drugs Act, Congress would help to ensure that this faith in medicine was justified — both for their constituents and for themselves.

Tied to the fear that all Americans (including Congressmen) faced danger from taking adulterated drugs was the fact that adulterations in drugs were extremely difficult for the consumer to detect. As the committee report noted, "a very limited number [of people] are qualified to detect frauds in medicine.' ${ }^{199}$ Even doctors could not reliably identify adulterated medicines - to require this to would mean that each doctor must also be an analytical chemist and have his own chemical laboratory ${ }^{200}$ Thus, patients were powerless to stop themselves from consuming an adulterated drug because they could not recognize adulterations. Even worse, patients could not rely on their trusted physicians to guarantee that the drug they prescribed was safe and effective. The Committee Report hinted that a layman could not be trusted to make his own evaluation of quality here; because of the undetectability of most adulterations to the average person, experts should shoulder the duty of evaluating the drugs.

The Committee appealed to broad social concerns in making its case for passage of House Bill 524. According to the Committee, Congress should address the issue of imported adulterated drugs because doing so would be acknowledging a duty to "protect...health and life" and advancing civilization as a whole ${ }^{201}$ The Committee made the novel argument that because all male citizens had the right to make their voices heard through voting, the government owed these citizens the duty to protect their "health and life." 202 Interestingly, the Committee made this argument about voting citizens, who were all male, and did not mention a parallel

\footnotetext{
${ }^{198}$ H.R. Rep. No. 30-664, at 22 (emphasis added).

${ }^{199} I d$. at 22 .

${ }^{200}$ See id.

${ }^{201}$ H.R. Rep. No. 30-664, at 16.

202 Id. at 16 .
} 
need to protect non-voting (female and non-white) citizens. According to the Committee Report, as the rights granted to citizens increased, so did the government's obligation to protect its citizens' health 203 The Committee acknowledged that this was a somewhat paternalistic idea of government, yet praised the governments of Europe who had already passed laws protecting the public health of their citizens ${ }^{204}$ The Committee compared the United States government to the governments of European nations with sanitary codes on their law books, almost in a competitive way, as if Congress should be motivated to pass this bill in order to keep up with the legislation of other nations.

Yet the Committee did not rely solely on a competitive instinct by Congress to achieve passage of the bill. It dug much deeper, and suggested that

the impulse to protect from, and to alleviate, disease in other, springs from a higher source - it flows from the fountain of man's moral nature, from that higher, holier feeling which prompts us all to do good to our fellows-from that philanthropy which makes every man our brother-his suffering and his health, no only our solemn trust and charge, but our pleasurable duty and care ${ }^{205}$

The Committee Report went on to praise all that the medical profession has done for humanity, from checking the spread of smallpox and plague, to making cholera more bearable to deal with ${ }^{206}$ Through the efforts of doctors, "the lives of millions [have] been spared for future usefulness.' 207 By conflating prevention of adulteration in drugs with the human instinct to help others and to save lives, the Committee made it very difficult for representatives to vote against the bill. For if a Congressman believed the Committee's arguments, voting against House Bill 524 would be like voting against the medical profession or against helping to ease another's pain. This was a powerful strategy on the part of the Committee-it made voting 
against their bill seem practically immoral.

The Committee also characterized a vote against the bill as a vote against progress in fighting disease. After cataloguing the advances of medicine over the years, and describing how medicine had progressed from "incantation and charms" to "a natural science," the Committee reminded Congress that all medical advances were moot if the drugs that doctors prescribed were either dangerous or ineffective due to adulteration ${ }^{208} \mathrm{In}$ overblown language, the committee report argued that "in vain do we push investigation into the laws of disease; in vain may pharmacy and chemistry point out and provide the curative agency of means, if those means themselves, through mercenary fraud, are despoiled of their power to heal." 209 Thus, according to the Committee, Congress would be rejecting all medical advances of the past by voting against the House Bill 524.

Finally, the Committee appealed to Congress as a protector of the helpless and the innocent. The committee report divided the world into two teams: "every man, woman and child, on the one side, and the foreign fabricator, or dishonest importer, on the other.' 210 Clearly, Congress was supposed to ally with the honest men, women, and children of this country - it would be practically immoral for it to back the "foreign fabricator." The Committee likened the shippers of adulteration of drugs to "the use of the dagger" or "passing a counterfeit bill," from which Congress gladly protected its citizens ${ }^{211}$ The Committee pointed out the absurdity of ruling that "to pass a counterfeit bill is a crime, but to pass a counterfeit medicine is not." 212 Thus, Congress would have to be illogical as well as immoral to fail to pass this bill.

\footnotetext{
${ }^{208}$ Id. at $17-18$.

${ }^{209} I d$. at 18 .

${ }^{210} I d$. at 19.

${ }^{211} I d$. at 19.

${ }^{212} I d$.
} 


\section{The Floor Debates on the Bill}

The report of the Select Committee on the Importation of Drugs was dated June 2, 1848, and the House of Representatives passed the House Bill 524 the very same day 213 This would seem to indicate that the Representatives had not had the chance to thoroughly analyze the Committee Report before voting. Indeed, Representative Hunt's comments almost presume that Congress had not yet read the report-yet he urged immediate voting on the bill without debate: "if any discussion were necessary to satisfy the House of the propriety of passing this bill, [Hunt] would suggest that the able report of the Select Committee should be read.' ${ }^{214}$ Representative Hunt got what he asked for, as there was virtually no House debate. Only Hunt and Representative Edwards spoke about the bill before the chamber voted on it. Representative Edwards, the chairman of the Select Committee on the Importation of Drugs, urged the House to act quickly on the bill ${ }^{215}$ He had been informed that foreign drug shippers were aware of the imminent passage of the bill, and were increasing the amounts of adulterated drugs they were sending to the United States in order to beat its passage ${ }^{216}$ In order to catch these vast quantities of adulterated drugs before they entered the country, Congress needed to pass the bill. ${ }^{217}$ Before urging Congress to vote immediately, Representative Hunt told Congress that the bill was "of vital importance to [the] country," and had been examined by "a select committee of medical men," who had expertise on the issue ${ }^{218}$ Hunt appealed to Congress to remedy the

\footnotetext{
${ }^{213}$ See Cong. Globe, $30^{\text {th }}$ Cong., $1^{\text {st }}$ Sess. 810 (1848).

${ }^{214} I d$.

${ }^{215} I d$.

${ }^{216} I d$.

${ }^{217} I d$.

${ }^{218} I d$.
} 
problem that had been "very injurious" to the American army during the war with Mexico ${ }^{219}$ After these few remarks - and no questions by members of Congress - on the bill, the House voted on and passed the bill 220

The Senate took up the House bill on June 20, 1848 There was slightly more debate in this chamber. Two senators expressed the opinion that the bill would be worthless in preventing adulterated drugs from reaching the public. Senator Calhoun "expressed his apprehension that the bill could not have the effect of terminating the evil." $\sqrt{222}$ Benator Dickinson noted that the bill "belonged to that class of legislation which attempts to put the bell on the cat.' ${ }^{223}$ By this, Dickinson likely meant that while the legislation may have sounded like a worthwhile solution to the problem of adulterated drugs reaching the public, in practice, its enforcement would not remedy the problem. He pointed to the large gaps left by the bill, such as the fact that "the materials would be brought here [to the United States], and the spurious drugs would be manufactured [here instead of abroad]. ${ }^{224}$ He thought if Congress "could stop the compounding of these drugs, interdict patients from taking, and physicians from prescribing, [it] might do some good." 225 Senator a group of mice were being regularly terrorized by an old cat who was killing them off, one by one. The mice got together to decide how to solve their problem, and numerous ideas were proposed. Finally, the wisest mouse suggested tying a bell on the cat's tail, so that the mice would always know where the cat was, and would be able to avoid it. This was hailed as a life-saving proposal until the mice realized that none of them were willing to actually tie the bell on the cat's tail. The story concludes with the moral that "It is one thing to say that something ought to be done. It is quite another matter to actually carry out the proposed task." (http://63.64.191.194/audio/bedtime1.html viewed on April 23, 2002).

Dickinson's analogy to this fable holds only at a broad level-meaning that like the bell on the cat, the Import Drugs Act sounded like a solution to the problem, but would not work in practice.

${ }^{224}$ Cong. Globe, $30^{\text {th }}$ Cong., $1^{\text {st }}$ Sess. at 858 .

${ }^{225} I d$.
} 
Dickinson demonstrated through his comments that he recognized that the adulteration of drugs was a serious problem, but felt that this bill was not the way to solve it.

The defenders of the bill were led by Senator Dix. His comments focused on the severity of the problem. He "thought it the duty of Congress to take some steps to terminate the evil," although "he did not know whether Congress had power to put an end to the evil.' ${ }^{226}$ In essence, Dix's comments point to a feeling that Congress had to do something about the awful problem, even if what they did was an incomplete solution. For Dix, achieving partial success was better than achieving no success. The Senator refused to put resolution of the problem on the backs of doctors, because "the physician seldom compounds the medicine, and cannot always detect what is spurious, as the compounding is left to the apothecary.' 227 Other defenders of the bill relied on the endorsement that medical experts had given it ${ }^{228}$ Like Dix, they focused on "diminishing" the problem, rather than solving it ${ }^{229}$ Senator Davis of Massachusetts said that "if we can stop the importation of the spurious drugs from abroad, we shall know how to deal with those who may choose to go into their adulteration in the United States." 230 And with that, the bill was passed 231 Considering all the ramifications of this bill, it is quite shocking that Congress debated so little on this bill. The Import Drugs Act had the potential to affect American relations with other countries as it limited imports by certain foreign manufacturers. It would affect American businesses as well, specifically those merchants 
who regularly purchased the inferior drugs from abroad. There were no questions from Congressmen on which standards of drugs to use, on what would be done with drugs condemned as adulterated, on what the qualifications of the special examiners would be. In the end, the bill passed, and it seems that Congress satisfied itself that minimizing the problem of adulterated drugs was the best it could do at the time. It remained to be seen how the implementation of the Act would play out. 


\section{Chapter 4:}

\section{The Implementation of the Import Drugs Act of 1848}

Once the Import Drugs Act passed Congress in June of 1848, the easy part was over. The Act had sailed through Congress with almost no debate, but as of July of 1848, the United States Customs Service had to put the Act into effect ${ }^{232}$ This would require a great deal of work, especially on the part of the special examiners who were hired to inspect all imported drugs. The Act brought together the Customs Service and the medical profession together in a new way. The special examiners working for Customs had to have enough training and education to be able to determine if the drugs they scrutinized met the definition of adulterated or spurious. They had to be masters of tests to ferret out adulterations and possible deterioration. They had to be familiar with the whole pharmacopoeia of drugs. With these heavy task before it, the Customs Service set out to end the importation of adulterated drugs.

In this chapter, I examine the state of the Customs Service at the time the Act was passed, and question whether the agency was prepared to deal with the responsibility of enforcing the Act. I describe the public response to the passage of the Act, and then lay out the mechanics of how the Customs Service implemented the Act. I close the chapter with an analysis of the short-term success of the Act in identifying and condemning adulterated drugs 233

\footnotetext{
${ }^{232}$ On July 8, 1848, the Secretary of the Treasury sent a "circular" to all ports of entry advising the Customs Service of the Import Drugs Act, and providing instruction for compliance. See Thomas O. Edwards, Operation of the Law to Prevent the Importation of Adulterated Drugs, Ec., H.R. Exec. Doc. No. 30-43, at 3 (1849) [hereinafter Operation Report].

${ }^{233}$ This paper seeks to situate the passage of the Act in an historical context, and to look only at its immediate results. As such, the long-term effects of the Act and the ways in which the Act interacted with later laws are beyond its scope.
} 


\section{The U.S. Customs Service in 1848}

The United States Customs Service did not have a very strong reputation at the time Congress passed the Import Drugs Act. During the 1800's, Customs was extremely politicized, with its officers turning over with each change of administration ${ }^{234}$ One gained a lucrative appointment to a job in the Customs Service by professing party loyalty and by cashing in on family and political connections ${ }^{235}$ When the administration shifted from Whig to Democrat in 1853, there were 27,000 applications for approximately 700 positions in the New York customhouse ${ }^{236}$ From the mid-1830's to the mid-1840's, the Customs Service had been rocked by scandals of embezzling Collectors. The Collector of the Port of New York, a political appointee of President Jackson, made off to London in 1838 with an estimated $\$ 1$ million dollars, which he had skimmed from the Customs pot during his tenure ${ }^{237}$ Cartoons from the 1830's and late 1840's revealed the taint of scandal surrounding the Customs Service, and implied that its officers could be bought off to get around the laws ${ }^{238}$

Relying on the Customs Service to examine imported drugs was an interesting way for Congress to attack the problem of adulterated drugs. When the Import Drugs Act was proposed in 1848, the duties of the Customs Service included collecting tariffs on imported goods, which was primarily an economic task. With its new

\footnotetext{
${ }^{234}$ Carl E. Prince \& Mollie Keller, Dept. of the Treasury, The U.S. Customs Service: A Bicentennial History 106 (1989) [hereinafter Bicentennial History].

${ }^{235}$ Id. at 106. For a discussion of the corruption permeating the United States Customs Service during the 1800's, see id. at 95-106.

${ }^{236} I d$. at 106 .

${ }^{237}$ Id. at $100-102$.

${ }^{238}$ See, e.g., id. between 158-159: "Caricature following New York customhouse scandals, 1838. Library of Congress" depicting two subtreasurers embracing and praising each other for their corruption; and "Customs heads roll with the changing of the guard, 1848-1849. Library of Congress" depicting a line of men from the Custom House being guillotined.
} 
responsibilities under the Import Drugs Act, Customs would play a greater role in determining the quality and acceptability of imported goods. The only model Customs had to follow in this genre of legislation was the 1842 Tariff Act ${ }^{239}$ This 1842 law forbade the importation of obscene materials, so Customs officials had to condemn any they found in their inspections ${ }^{240}$ The Import Drug Act demanded more, however, in that it required a Customs official to conduct scientific tests to determine if a drug was of the requisite strength and purity to enter the country. With obscene material, Customs probably did not have to conduct any identifying tests, as its officials likely "kn[ew] it when [they] s[aw] it," much as Justice Potter Stewart did more than one hundred years later when he defined obscenity 241

Along with the corruption that plagued it, the Customs Service was in poor organizational shape at the time of the passage of the Act. It was underfunded and understaffed, having grown immensely in the preceding 20 years ${ }^{242}$ ts organizational structure, however, had not changed with it. In June of 1848 , the entire Customs Service was still under the aegis of the Secretary of the Treasury, who was theoretically responsible for familiarity with all goings on of the thousands of employees and seizures of the Service ${ }^{243}$ As imports and exports skyrocketed, and the number of points of entry to the United States exploded, the

\footnotetext{
${ }^{239}$ See Tariff Act of 1842 , ch. 270, $\S 28,5$ Stat. 566. The Secretary of the Treasury explicitly compared the two laws in his letter to Congress supporting legislation prohibiting the importation of adulterated drugs. See H.R. Rep. 30-664, at 4.

${ }^{240}$ The section of the Tariff Act of 1842 that banned importation of obscene materials provided:

And be it further enacted, That the importation of all indecent and obscene prints, paintings, lithographs, engravings, and transparencies is hereby prohibited; and no invoice or package whatever, or any part thereof, shall be admitted to entry, in which any such articles are contained; and all invoices and packages whereof any such articles shall compose a part, are hereby declared to be liable to be proceeded against, seized, and forfeited, by due course of law, and the said articles shall be forthwith destroyed.

See Tariff Act of $1842, \S 28$.

${ }^{241}$ See Jacobellis v. Ohio, 378 U.S. 184, 197 (1964) (concurring opinion, Stewart, J.).

242 See Bicentennial History, at 96-98.

${ }^{243}$ Id. at 97 .
} 
Customs Service was in dire need of a leader who could devote his full time to the job. Finally, in 1849, the position of Commissioner of Customs was created by Congress, thereby relieving the Secretary of the Treasury of his control 244 The Commissioner of Customs had the direct responsibility for the day to day administration of Customs and for its "fiscal integrity." 245 As mentioned above, the number of points of entry into the United States was increasing with each new addition of territory to the nation. However, the vast majority of all good imported into the United States came through the Port of New York. As of 1829, the Port of New York supervised two thirds of all imports into the United States ${ }^{246}$ As thousands of pounds of drugs and medicines were among this tally, this port in particular faced challenges in implementing the Import Drugs Act ${ }^{247}$ In addition to having a large amount of import/export traffic, the Port of New York was known as a hotbed of corruption within the Customs Service. Indeed, "the volume of goods passing through that harbor and the dynamic increase in customs personnel simply magnified the corruption possible in [New York]." ${ }^{248}$ One commentator later described the problems at the Port of New York during the 1830's and 1840's as an "unredressed major national dilemma."249 These problems notwithstanding, the Customs Service did have ample experience in enforcing controversial or unworkable laws. Several times before, Congress had passed laws over great public outcry, making it very difficult for Customs to enforce them on an angry and resistant populace ${ }^{250}$ There are numerous accounts of Collectors, the head Customs officials at each port of entry, simply refusing to enforce the embargo, due to the public sentiment of their

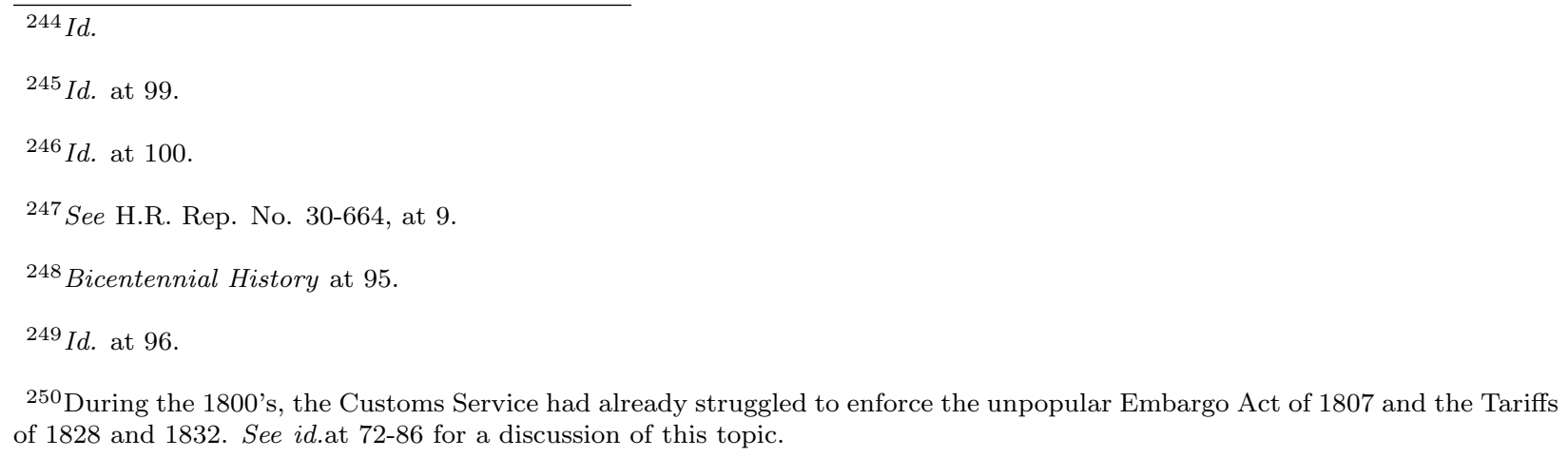


communities and to the practical impossibility of complying with the law. Congress also had the habit of not appropriating enough money to enforce its laws - often there were not enough Customs officers on the payroll to handle the burgeoning number of imports and exports ${ }^{251}$ As will be discussed later in this chapter, Congress simply added to this problem with its passage of the Import Drugs Act. When Congress did not provide enough resources to accomplish its objectives, there was little the Customs Service could do.

Thus, by the time the Act was passed in June of 1848, there were already certain expectations of how Customs operated - expectations held by Congress, the Customs Service, by importers and exporters, and by the public at large. In the years prior to 1848, the Customs Service "had... found itself understaffed and underfinanced, yet compelled to bear the brunt of enforcing badly drawn legislation." ${ }^{252}$ Circumstances would not change with the passage of the Import Drugs Act. The stain of corruption was still very much associated with the Customs Service. Though it may be going too far to say that importers regularly expected to bribe Customs officials to reduce their import taxes, or to get suspicious goods smuggled in, it is undoubtedly the case that all parties involved in importation or exportation knew that bribery was always an option 253 Given the corruption, poor organization, and underfunding of the Customs Service in 1848, it is unclear how Congress honestly could have expected the agency to stop the flow of adulterated foreign drugs. 


\section{Public Response}

The response of the public to the passage of the Import Drugs Act was diverse. According to Dr. T.O. Edwards, who toured Customhouses to review compliance with the Act, "no bill ever met with more decided opposition on its introduction than the act of the $26^{\text {th }}$ of June last." 254 Edwards noted that, "Many commission houses and drug brokers attacked it, with a violence unexpected by its friends; while one or more leading commercial journals in New York, for weeks before the passage of the law, devoted large space to its attack, and after their arguments had been answered, resorted to abuse of its authors and friends.' 255 Such abuse was not entirely unwarranted, as the import community had good reason to protest the Act. Drug importers stood to lose a great deal of business if the goods they hoped to buy and sell were condemned by Customs. Other participants in the drug market were less resistant to the Act. The Collector at the New York Custom House claimed to be "credibly informed that regular dealers in drugs express themselves satisfied that the law is a necessary and beneficial one, and absolutely necessary to the prevention of injustice and injury to the community.'256

Other constituencies expressed their happiness that Congress had passed the Import Drugs Act. Unsurprisingly, the medical community was especially pleased. The Boston Medical and Surgical Journal lauded the Act's passage on July 12, 1848 ${ }^{257}$ The journal thanked the National Medical Association (which became the

\footnotetext{
${ }^{254}$ Operation Report, at 2. As the reader will remember, Dr. Edwards headed the Select Committee on the Importation of Drugs, and had been the strongest proponent for the passage of the Act.

${ }^{255}$ Operation Report at 2.

${ }^{256}$ Id.at 3.

${ }^{257}$ Boston Medical and Surgical Journal, July 12, 1848.
} 
AMA) for helping to stop the "death-destroying traffic in adulterated drugs" by lobbying for the Act ${ }^{258}$ Dr. Edwards was praised for his work on the Act by a resolution of the New Hampshire Medical Society at its annual meeting on June 5, 1849259

\section{Enforcement Mechanics}

Enforcement of the Import Drugs Act began on July 8, 1848, less than two weeks after the Act was passed by Congress. The Customs Service had to decipher the requirements of the Act, and make decisions about how to practically comply with it. The most pressing task Customs faced was finding the special examiners who would evaluate all drugs coming into the ports. Customs also had to find equipment and space for testing the drugs, as well as figure out how and where to destroy the drugs that were condemned. In this section of the chapter, I look at the decisions Customs made in interpreting the Act, and describe some of the mechanics of how the Act was implemented.

The special examiners who would analyze all the drugs coming through the ports of entry were the key element to the Act's success. As such, honesty and devotion to the job were important characteristics needed in the examiners. To ensure that the special examiners recognized the heavy weight of their duties, Customs required them to swear an oath of loyalty to the United States before beginning their jobs ${ }^{260}$ The examiners had to swear that they would "diligently and faithfully perform the duties of [the] office as prescribed by 258 Id.

${ }^{259}$ Minutes of the Fifty-Ninth Annual Meeting of the New Hampshire Medical Society, June 5 , 1849.

${ }^{260}$ Import Drugs Act, ch. 70, §6, 9 Stat. at 239. 
the act to prevent the importation of adulterated and spurious drugs and medicines, approved June 26, 1848, and w[ould] use [their] best endeavors to prevent and detect frauds upon the revenue of the United States."261 The examiners also had to swear to "support the Constitution of the United States.' 262 These oaths were basically equivalent to the oaths that any Customs inspector had to swear at the time. Given the corruption inherent in the Customs Service at the time, we have no way of knowing whether the oaths kept the examiners honest in performing their duties.

Once they assumed their duties, the drug examiners faced difficulties likely unanticipated by Congress when it passed the Act. Even if Congress had considered the issues, it failed to resolve them in the language of the statute. Drug examiners faced dilemmas over what to do with drugs that were already in storage at customhouses ${ }^{263}$ r how to treat cargo that was shipped before the passage of the Act, but arrived at an American port after the Act's enforcement had begun ${ }^{264}$ Congress did not list exemptions to the Act's requirements, so the Collectors and the Secretary of the Treasury were left to interpret it themselves. The parties involved struggled with issues of fairness and the intended effect of the law in making their rulings. The examiners realized that condemning cargo shipped before the Act went into effect would be like enforcing an "ex post facto" law, yet failing to condemn the adulterated cargo would have defeated the Congressional intent of prohibiting adulterated drugs from entering the United States ${ }^{265}$ These Customs officials were

\footnotetext{
${ }^{261}$ General Regulations under the Customs and Navigation Laws of the United States (1857 ed.) at 160 [hereinafter General Regulations].

${ }^{262} I d$.

${ }^{263}$ Letter from C.W. Lawrence, Collector at the New York Custom House, to Robert J. Walker, Secretary of the Treasury, dated July 21, 1848. The letter asks for advice regarding deteriorating rhubarb root in the Customs' warehouses. [Letter \#196 in Hutt Binder].

${ }^{264}$ Letter from C.W. Lawrence to McClintock Young, Acting Secretary of the Treasury, dated September 11, 1848, asking that the Secretary exempt from condemnation adulterated drugs shipped before June 26, 1848. [Letter \#229 in Hutt Binder].

${ }^{265} I d$.
} 
required to make daily judgment calls, in addition to performing the rest of their demanding duties.

The types of tests conducted by the special drug examiners were numerous and complicated. To test the strength of various acids, for example, the examiners had to determine the "specific gravity" of the liquid, which was done with a hydrometer ${ }^{266}$ However, one of the examiners describing the process cautioned that hydrometers were "frequently inaccurate and deceptive instruments" and suggested several ways to determine the accuracy of the instrument ${ }^{267}$ Moreover, "accurate determination of the specific gravity [of liquids]... [wa]s not very easy for those who are not skilled in manipulating. . [the] instruments ${ }^{268} \mathrm{With}$ so much potential for error in these tests, it is a wonder that importers accepted them as valid when the results were so determinative of an importer's profits. Other tests required burning substances, mixing chemicals, evaporating out precipitates, and making very precise measurements - all of which tasks were extremely time consuming and demanding ${ }^{269}$ Testing could take more than a day for some drugs. The special examiner all by himself was charged with keeping track of all the phases the testing was in, conducting the tests, keeping

When a test is to be made, reduce some of the crystals to a fine powder, and dry it between a few folds of bibulous paper, pressing it between the leaves of a book, or in some similar contrivance, until the paper ceases to absorb any moisture. Take 100.5 grains by weight of this powder, and transfer it into a small porcelain dish, add about once ounce of water, and heat to near the boiling point. Then take considerably more of the acid to be examined than is supposed to be necessary for saturating the above amount of alkali, pour it into a small and light flask, and weigh. Now add the acid gradually to the alkaline solution, stirring constantly with a glass rod, care being taken not to add too much acid at a time, lest such a violent effervescence should ensue as would cause the jerking away of some of the liquid. When the violence of the effervescence begins to abate, test the solution after each successive addition of acid with blue litmus-paper. As soon as the paper is slightly reddened, stop adding the acid, and boil the liquor a few moments to expel all the carbonic gas absorbed by it. If the test-paper continues to be slightly reddened by the solution, it indicates that enough acid has been added; it if is not reddened, add a few more drops of acid, until the desired reaction takes place. Then replace the flask upon the balance, and add weights enough to restore the equilibrium. This weight of course shows the amount of acid consume in neutralizing 100.5 grains of bicarbonate of alkali, provided none of the acid has been spilled during the operation. The inexperienced manipulator generally finds it difficult to hit exactly the point when a sufficient amount of acid has been added to neutralize the alkali, and frequently adds too much, before he discovers the mistake. It is then necessary to repeat the experiment a second, and perhaps a third time, before that point is accurately determined.
} Id. at 7-8 (emphasis added).

${ }^{269}$ For additional descriptions of the tasks the special examiners used to evaluate drugs for strength and purity, see generally, Examinations. 
records, and boarding ships to ensure that every single cargo box of drugs or medicines was examined. A small error in measurement or calculation could result in either the mistaken condemnation of valuable, genuine drugs, or the erroneous acceptance of a shipment of contaminated or weak drugs.

The Customs Service also had to interpret what Congress intended by providing that imported drugs were acceptable if they met the standards of five different pharmacopoeia $2{ }^{270}$ Customs regulations provided that if the drug was manufactured in England, Scotland, France, or Germany, it had to measure up to the pharmacopoeia standards of the respective country of production ${ }^{271}$ If the drug had been manufactured in another foreign nation, it had to meet the standards of the United States Pharmacopoeia ${ }^{272}$ In this way, the Customs Service filled the gaps in the Act as written by Congress, since the Act did not specify which pharmacopoeia standard to use for any given shipment. The special examiners still had to maintain knowledge of the current state of all five pharmacopoeia, however, in order to perform their assigned tasks.

When the examiners found that imported drugs did not meet the standards specified under the Act, Customs officials took certain steps. First, an examination was performed to determined whether any part of the imported cargo met the strength and purity standards of the Act ${ }^{273}$ If any parts of the cargo were of sufficient strength and purity, they could be sold and "the proceeds accounted for as in ordinary cases of forfeiture. ${ }^{274}$ The adulterated portion of the cargo had to be destroyed. This policy indicated concern about waste of drugs of adequate quality; though Customs aimed to prevent adulterated drugs from entering

\footnotetext{
${ }^{270}$ See supra pp. 44-45, discussing Congress's decision to include all five pharmacopoeia.

${ }^{271}$ See General Regulations at 156.

${ }^{272} I d$.

${ }^{273} I d$. at 159.

${ }^{274} I d$.
} 
the United States, it did not want to interfere with trade by overcondemning. The same issues had been faced by Customs with the 1842 Tariff Act that prohibited importation of obscene materials. Customs officials were often unsure whether they were supposed to condemn entire shipments of goods, or just the few obscene articles within them 275 t seems that in enforcing the Import Drugs Act, Customs was consistent in destroying only the adulterated portions of shipments.

Customs officers also followed certain procedures in destroying the inferior drugs ${ }^{276}$ The special examiner had to choose a place and means of destruction, and a customs officer had to ensure that the drugs were taken there and destroyed $\sqrt[277]{27 x t e n s i v e ~ d o c u m e n t a t i o n ~ a b o u t ~ t h e ~ s h i p m e n t ~ h a d ~ t o ~ b e ~ k e p t, ~ i n c l u d i n g ~ d e s c r i p t i o n s ~}$ of the condemned articles, the name of the importer, the date of shipment, and the name of the ship and the place of origination 278 The Customs officer had to certify that the goods had been destroyed, and file the records in the Custom-house ${ }^{279}$ These regulations sought to ensure that the adulterated goods actually were prevented from entering the country. However, given the reputation of Customs at the time, it is impossible to know whether the certifications of destruction filed by the officials were accurate. As bribes were a way of life in other areas of Customs, they also may have been used by foreign drug manufacturers to get around the condemnation of their adulterated goods.

Interestingly, the labeling requirements of the Import Drugs Act were treated differently than the strength and purity requirements. Under the labeling requirement, Customs appraisers had to see that "the true name of the manufacturer, and also the place where said articles were prepared, are 'legibly affixed to each

\footnotetext{
${ }^{275}$ See Bicentennial History, at 252-253 for a discussion of the Tariff Act of 1842, and Customs' relationship to pornography over time.

${ }^{276}$ General Regulations, at 162-163.

${ }^{277} I d$.

${ }^{278} I d$. at 164 .

${ }^{279} I d$.
} 
parcel by stamp, label, or otherwise. ${ }^{280}$ But, not all imported drugs required this label: under the Act, only medicinal preparations "usually imported with the name of the manufacturer, and the place where prepared, permanently and legibly affixed to each parcel." ${ }^{281}$ Thus, the labeling requirement touched only a limited group of imported drugs - those that were regularly labeled with quite a bit of information about their manufacture. If there were imported drugs missing the required label, the Customs Service would report the case to the United States district attorney to prosecute ${ }^{282}$ Customs could not condemn imported drugs for violating the labeling requirement; only through additional legal proceedings could the drugs be seized and condemned ${ }^{283}$ The labeling requirement differed from the strength and purity requirements in that there are no reports of drugs being condemned for violating the labeling requirement, while there were large amounts of drugs condemned as adulterated 284

One of the major difficulties the Customs Department faced in executing the Import Drugs Act was Congress' unwillingness to fund it adequately. When Congress passed the Act, it did not appropriate any additional funds for its implementation. The salaries to be paid to the examiners were to come out of funds "not otherwise appropriated" in the Customs' treasury ${ }^{285}$ The Act specifically provided that the special examiners of drugs must come from the existing members of Customs if at all possible ${ }^{286}$ Any appointment that

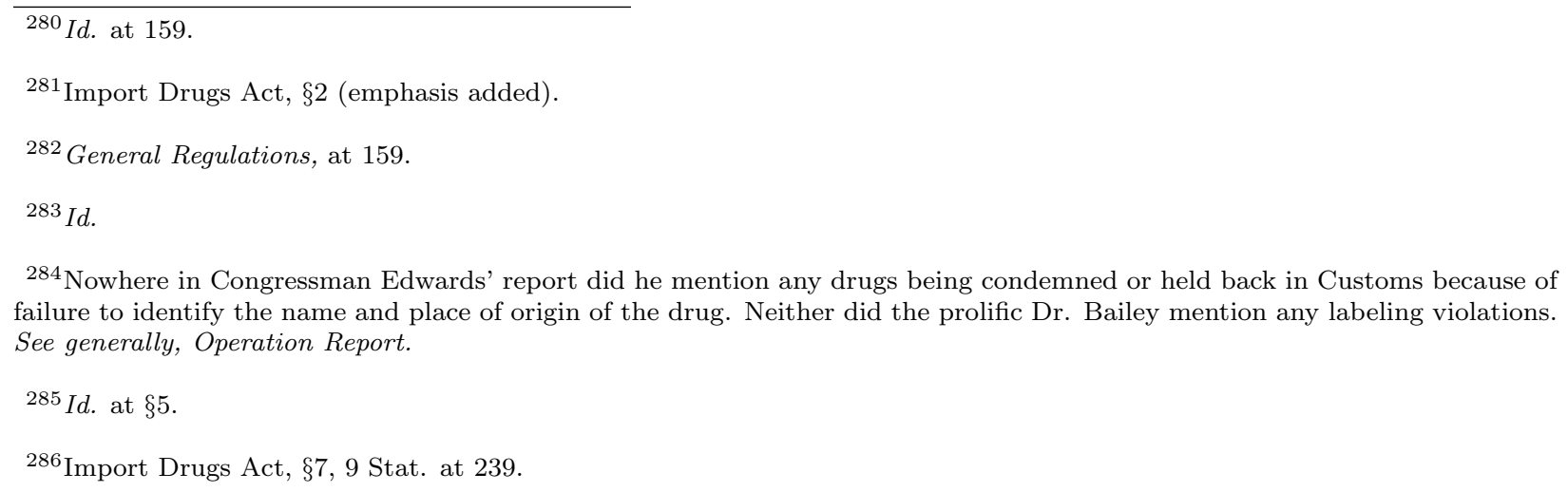


increased the number of employees of the Collection Office was unacceptable under the Act - if a person from outside the Customs Service was made special examiner of drugs, then an existing employee of that Customs Office had to eliminated ${ }^{287}$ When the Customs House at the port in Salem, Massachusetts hired local apothecary G.H. Pinkham as its special drug examiner, presumably it had to eliminate one of its existing positions, as Pinkham had not previously been employed by the Customs Service 288 Congress was not willing to spend much, if any, money to see that the Act succeeded.

At the time the Import Drugs Act was passed, the Customs Service was on a very tight budget. As noted earlier, this budget may have been further limited by the embezzling done by many top Customs officials. Customs was already engaged in cost-cutting measures, even before passage of the Act. In a letter sent to all ports in October, 1847, the Secretary of the Treasury had instructed all Custom Houses to limit their "confidential inspectors" to one per port, to pay the inspectors per diem for each day they could prove they worked, and that they must not pay these inspectors more than $\$ 1200$ cumulatively per year ${ }^{289}$ The unappropriated monies that Customs was ordered to tap to fund the Act most likely did not exist.

In a way, Congress's failure to appropriate funds for the Act was in keeping with the practices of the time. Until June 30, 1849, Customs had to pay its expenses out of the duties it collected, before turning into the remainder to the Treasury Department ${ }^{290}$ f C Customs' budget was indeed limited by the amount of duties it took in, it is clear why opponents of the Import Drugs Act argued that it would end up reducing Customs' budget. For under the Act, when Customs seized or condemned adulterated drugs, it could not collect duties on them as it had previously been used to doing. In the Port of New York, where thousands of pounds of 
drugs were condemned under the Act, Customs surely did lose a substantial amount in duties.

\section{The Success of the Act}

\section{Edwards' Report to Congress}

The question on everyone's mind was whether the Import Drugs Act would be successful in reducing the problem of adulterated drugs. Thus, within months of the passage of the Act, Congress wanted a progress report 291 It asked Dr. T.O. Edwards of the Select Committee on the Importation of Drugs "to visit the ports of Baltimore, Philadelphia, New York and Boston, for the purpose of examination" to determine whether the Act was "fully and properly carried into effect." 292 Edwards' verdict was that the law was a success, for "whilst the law in its practical operation has not fulfilled the predictions of its enemies, it has more than realized the anticipations of its friends.' ${ }^{293}$ Edwards based his assessment on interviews with importers in the cities he visited, as well as the more than six hundred letters praising the Act he said he received ${ }^{294} \mathrm{He}$ was satisfied that as the law was implemented, views on it were becoming more and more positive, and only "a very limited number now advocate that freedom of trade which gives to the designing and dishonest drug dealer power not only over the health but the lives of the community." 295 The Act was so well-received,

\footnotetext{
${ }^{291}$ Operation Report, at 2 (references Oct. 10, 1848 letter from Congress requesting an update).

${ }^{292} I d$. (quoting the Congressional request of Oct. 10, 1848).

${ }^{293}$ Id. at 2.

${ }^{294} I d$.

${ }^{295} I d$. at $2-3$.
} 
Edwards wrote, that he "was unprepared for so full an expression of its benefits." 296

As part of his evaluation of the effectiveness of the Act, Edwards requested a report from the New York Custom House. The Collector, who was in charge of the Custom House as a whole, referred Edwards to Dr. M.J. Bailey, who had been named the special examiner of drugs for the New York Custom House, and who had been a strong advocate for the bill's passage a few months earlier ${ }^{297}$ The Collector did not have records of imported drugs - adulterated or pure - so had to rely on Bailey for the data. Though he was unaware of the specific effects the Act was having on imports in his own port, the Collector demonstrated strong support for the Act. He addressed complaints that the condemnation of adulterated drugs had led to a reduction in duties collected by Customs by arguing that the protection to health and safety afforded by the Act more than compensated for the lost revenue ${ }^{298}$ The Collector went even further to argue that the Act would eventually lead to increased revenue to Customs, as more superior quality drugs (with a correspondingly higher duty to pay) would be imported to fill the gaps of the adulterated drugs ${ }^{299}$ This type of positive attitude from a high-ranking member of Customs must have been highly encouraging to Dr. Edwards. In his report to Congress, Edwards made concrete statements of the amounts of adulterated drugs seized by Customs in the months since the bill's enactment. In Boston and in Baltimore, only one shipment had been condemned in each port ${ }^{300}$ In Philadelphia, no seizures of adulterated drugs had occurred ${ }^{301}$ Edwards explained that the cause of the small number of seizures was the small number of drugs generally imported 
through these specific ports and the tendency of importers not to present adulterated drugs at port when they would necessarily be rejected ${ }^{302}$ In the Port of New York, however, there were quite a number of seizures of adulterated drugs pursuant to the Act. Dr. Bailey's records included thousands of condemned pounds of jalap root from Mexico, rhubarb root from England, opium from France and England, and cinchona bark from "Carthagena" (Mexico) ${ }^{303}$ Some of the condemned drugs were "greatly adulterated...and also deteriorated by age and other causes." 304 Others had had their "active properties" removed to make extracts, while the jalap root was of "spurious or bastard varieties, mixed with a small proportion of the genuine root." $305 \mathrm{Of}$ particular interest, especially in light of the heavy use of quinine by American troops in Mexico, were the shipments of yellow bark and cinchona bark that were condemned. The condemned was of a "bastard variet[y] that afford[ed] no quinine and very little if any cinchonine." ${ }^{306}$ As such, it was "worthless for medicinal purposes.' ${ }^{307}$ Before the Act, according to Edwards' letter, such bark would have passed Customs, been sold at a low price, powdered, and then "sold in large quantities to the unsuspecting for the genuine article.' ${ }^{308}$ Based on the quantities of drugs condemned in New York, Edwards' report indicated definite progress in preventing adulterated drugs from entering the country.

Though the amount of drugs condemned in New York was substantial, very few of the importers whose goods were condemned took advantage of the appeal provided for in Section 4 of the Act ${ }^{309}$ In New York,

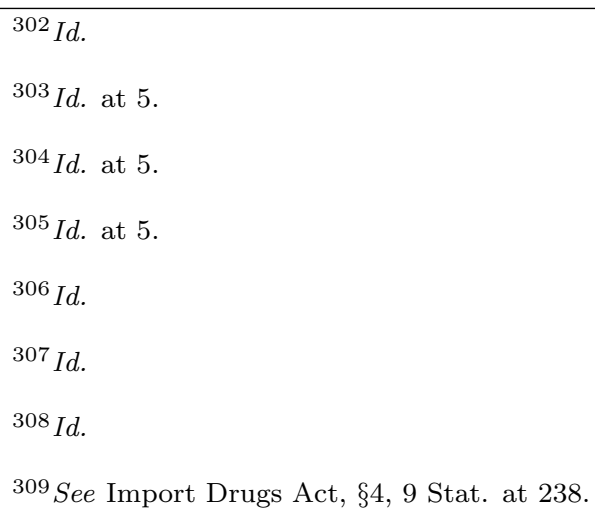


of the 27 shipments of drugs that were rejected between July 8, 1848 and December 23 1848, only two appeals occurred ${ }^{310}$ The condemnation of one of these shipments stood after evaluation by an independent chemist ${ }^{311}$ The other appealed shipment of six cases of opium was ultimately split into two parts following re-evaluation by a chemist ${ }^{312}$ Four of the cases were still condemned as adulterated and re-exported, but two of the cases were allowed to pass through Customs after an analytical chemist found "the article genuine and pure, only of a weak standard of strength." ${ }^{313}$ As discussed earlier in this chapter in the section on the mechanics of enforcement, the treatment of this shipment of opium indicated that Customs was consistently following a policy of condemning only adulterated portions of shipments. Indeed Edwards supported a policy of allowing the Customs inspector to condemn only the adulterated portion of a shipment, and to allow the good quality portion to enter the United States ${ }^{314}$ Such a policy would "rob the enemies of the bill of their principle objection, and would clearly demonstrate that those opposed to the traffic of adulterated drugs have no desire to trammel legitimate business." [315 Edwards' report also professed a high degree of support for the special examiners who labored under the Act. Edwards described them as "qualified and diligent," "determin[ed] to carry [the law] into execution [to] its utmost limit," and "fulfill[ing] the requisition of the law." ${ }^{116}$ Given that Customs was known as a place of political connections and corruption at the time, it is interesting that Edwards placed so much apparent faith in these examiners. Even when telling Congress that the inspectors at three of the major ports into the United States had condemned only two shipments

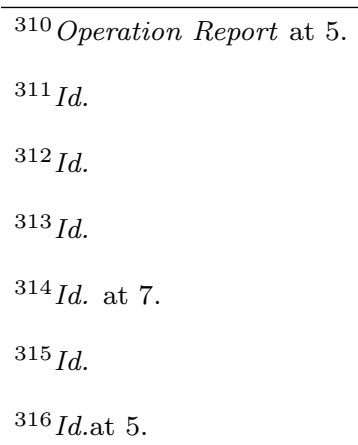


among them over the course of four months, there was no hint of irony in Edwards' praise of the inspectors' competence and devotion. Based on his pleasure with the performance of the inspectors, Dr. Edwards proposed increasing the salary of Dr. Bailey, the special examiner at the Port of New York. Under the Act, Dr. Bailey was making $\$ 1600$ per year, which was less than what the ordinary Customs appraisers at the same port earned for their services ${ }^{317}$ Edwards was successful in getting Congressional approval for a salary raise to $\$ 2000$ per year for Bailey, and also secured funding (\$1000 per year) for a clerk to assist the special examiner ${ }^{318} \mathrm{He}$ justified the salary raise by pointing out that Bailey had already condemned "a very large amount" of adulterated drugs, which was Congress' goal in passing the Act ${ }^{319}$ Edwards also described the enormity of Bailey's job: every single shipment had to be eyed by him—not only eyed, but tested. This was indeed a huge job for one man, and it is easy to believe Edwards' claim that Bailey "labored all day in his office, and a large part of the night in his laboratory.'320

Taken as a whole, Edwards' report reveals a number of biases on his part. He had been an ardent supporter of the bill as it worked its way through Congress, and the language he used to condemn those who opposed the enforcement of the Act suggests that he may have had certain results in mind when he began his investigations. Edwards aligned those advocating for "freedom of trade" with dishonesty and murderous intent, stating that they sought to have power "not only over the health but the lives of the community." "[21] He dismissed as mere "murmurings" the unhappiness that some commission houses had regarding the Act,

\footnotetext{
${ }^{317}$ Cong. Globe, $30^{\text {th }}$ Cong., $2^{\text {nd }}$ Sess., 323 (1849).

${ }^{318} I d$.

${ }^{319} I d$.

${ }^{320} I d$.

${ }^{321}$ Operation Report at 2-3.
} 
when these commission houses may have had valid economic arguments ${ }^{322}$ According to Edwards, these houses either had foreign interests in mind, or found the "almighty dollar" more important than "the lives and happiness of their fellow beings." 2323 This type of language echoed that found in the Committee Report drafted by Edwards, that aligned non-supporters of the law with evil, greed, immorality, and non-patriotism.

\section{Reports of Special Drug Examiners}

A few of the special examiners also commented on the results of the Act. These examiners wrote from their own experiences, and thus their reports come to the reader unmediated. However, the examiners also had the most at stake in describing the successes or failures of the Act. Their salaries and reputations were on the line, and if the Act failed to address the problem of adulterated drugs, these examiners were failures as well. The famous Dr. Bailey of the Port of New York and Dr. C.H. Peirce of the Port of Boston both had high praise for the Import Drugs Act from their vantage points as special examiners of imported drugs ${ }^{324}$

Both Bailey and Peirce found the Import Drugs Act beneficial because it had reduced the amount of adulterated foreign drugs that were presented for importation. Bailey attributed this to the publicity surrounding the proposal and passage of the Act, which he conjectured had spurred the importers to change their behavior and cease production of adulterated medicines ${ }^{325}$ According to Bailey, because the dishonest drug manufac- 
turers had dropped out of the market, the honest ones were doing increased business ${ }^{326}$ Peirce asserted that foreign drug manufacturers were deterred from exporting "fraudulent medicines" to the United States "when they [we]re aware of the strict examination such medicines must undergo here, with the certainty that they will be condemned if found to be spurious, or below the appointed standard of purity.' $[327$ Both examiners also acknowledged that the Act had not touched the problem of domestic drug adulteration. Peirce admitted that adulterated medicines were indeed manufactured in America, but urged individual states and municipalities to legislate against this problem ${ }^{328}$ He was quite satisfied that the Act had resulted in increased public awareness of drug adulteration. Peirce predicted that "on being made aware of the extent to which this is carried on, they will be cautious of whom they purchase, and will thus indirectly help in carrying out the provisions of the law.' ${ }^{329}$ Bailey, too, came to admit that medicines were adulterated domestically, and had changed his mind about the honesty of his fellow Americans by the middle of 1849. In the spring of 1848, Bailey had told the Select Committee that the Act would not increase - and may even decrease-domestic adulteration of drugs. However, in his report to the New York Academy of Medicine in June, 1849, he acknowledged that Americans themselves were adulterating drugs:

To suppose that we have none among us engaged, or who will engage in the preparation and sale of spurious and adulterated medicines, is to place a higher estimate upon the conscientious scruples of that portion of our speculating and trading community with whom the almighty dollar is paramount to all other considerations, moral, if not divine, than, from my somewhat extensive observations, I am willing to concede ${ }^{330}$

\footnotetext{
Academy of Medicine, June 6, 1849) [hereinafter Bailey Operation Report].

${ }^{326} I d$. at 148 .

${ }^{327}$ Examinations, at iii-iv.

${ }^{328}$ Id. at iv.

${ }^{329} I d$.
} 
Even by June, 1849, "the fraudulent work of [American] hands [wa]s but too visible" for Bailey to ignore ${ }^{331}$ Bailey asserted that this practice of domestic adulteration of drugs was only "recently transferred to our shores." 2332 He was so dead-set against believing that Americans would stoop to adulterating medicines that he claimed that foreigners had come into America to adulterate the medicines there: "I have good reason to believe that we have at present those among us from abroad, who have so long been engaged in this particular line of business, that they have become perfect adepts at this base and deceptive art." ${ }^{333}$ Unfortunately, Bailey's tendency to scapegoat foreigners as the cause of even domestic drug adulteration may have prevented him from making more helpful recommendations to Congress. If examiners such as Peirce and Bailey had pushed harder for federal regulation of domestic drug adulteration, Americans might not have had to wait until the 1906 Food and Drug Act for such protections 334

\footnotetext{
${ }^{331} I d$. at 149 .

${ }^{332} I d$.

${ }^{333} I d$.

${ }^{334}$ The first federal law addressing the problem of domestic adulteration of drugs was the Federal Food and Drugs Act of 1906. See 34 Stat. 768 (1906).
} 


\section{Conclusion}

As this paper makes clear, numerous factors were involved in the passage of the Import Drugs Act of 1848. The adulteration of drugs was a severe problem, and there were surely many people who fought for it in order to protect the health and safety of their fellow man. In this paper, however, I have tried to shine light on motives or rationales of the Act's supporters that may not be evident on first glance. The self-righteous anger that the Committee Report expressed at the thought of American soldiers being given adulterated drugs was tied - consciously or not - to Congress' need to explain the high mortality rate of American soldiers. The physicians lobbying for passage of the Act also stood to gain from it-both in status and in income. In the end, while noble goals certainly played a role in the Act's passage, so too did the self-interests of the parties lobbying for and voting on the Act.

In this paper, I have also sought to capture some of the mundane practicalities of implementing the Act. Congress saddled the Customs Service with a huge task when it passed the Act. The special drug examinersprimarily the examiner for the Port of New York — had very demanding jobs, especially given the complicated procedures required to test the drugs for adulterations. The Customs officials faced the day-to-day disputes over the quality of a shipment of drugs, and were required to make judgment calls that Congress never anticipated when it passed the Act. Looking closing at the enforcement procedures of Customs also clearly revealed that Congress did not provide nearly enough funding for the Act. Catching every single adulterated drug that came through the Port of New York would have required a decent-sized staff, who could share 
the duties of inspecting, testing, record-keeping, settling disputes, and destroying the condemned articles. Without adequate funding, the Import Drugs Act could not reach its full potential.

Ultimately, the Import Drugs Act was both a success and a failure at addressing the problem of adulterated drugs. As demonstrated in this paper, the new Customs examiners did condemn large amounts of adulterated drugs under the Act - drugs that previously would have entered the country and been sold to the public. In this sense, the Act was successful, as it did reduce the quantity of foreign adulterated drugs reaching American citizens. However, American citizens were still being sold adulterated medicines - even after passage of the Act. The Act could not reach domestically-produced adulterated drugs, so was doomed to failure in this area. If nothing else, the Import Drugs Act revealed how strong the domestic production of adulterated drugs was. And, more than fifty years later when Congress was debating the 1906 Food and Drugs, the Import Drugs Act of 1848 may have reminded it that in order to effectively solve the problem of adulterated drugs, it needed to regulate domestically. 